\title{
Horizon Teks Walisongo: \\ Membangun Demokratisasi Keberagamaan Individu
}

\author{
Ubaidillah Achmad \\ Dosen IAIN Semarang \\ almaulal589@yahoo.com
}

\begin{abstract}
This paper deals with the way how Muslim society applies its religious (Islamic) doctrines. It discusses how social values and behaviors taught by Walisongo are preserved by the society as to bring them to their life's objective. This paper demonstrates that the achievement of their life's goals can realize the development of the quality of the model of both individual and collective religiosity, and argues that this in turn will build a harmonious social life within civil society, free from ethnical and religious conflicts.
\end{abstract}

Kata kunci: Walisongo, relijiusitas, ethics, dan doktrin keagamaan.

\section{Pendahuluan}

Dalam realitas perkembangan umat manusia (wäqi'at al-'umrān albasyar ${ }^{\prime}{ }^{\prime}$, prinsip etika masih dipandang melalui dua sudut pandang. Pertama, prinsip etika muncul setelah ditetapkan perundang-undangan atau peraturan penguat undang-undang dasar. Kedua, prinsip etika sebagai sumber undangundang. Artinya, sebuah undang-undang atau peraturan dibuat karena adanya prinsip etika universal yang dipedomani oleh masyarakat pada umumnya. Karenanya, undang-undang atau peraturan yang dibuat kemudian harus disesuaikan dengan prinsip etika yang sudah berkembang dan mendasari aktivitas sosial-keagamaan masyarakat. Jika setiap undang-undang atau peraturan pengganti undang-undang dibuat dengan tidak mempertimbangkan dasar etikanya, maka tatanan sosial kemasyarakatan tidak akan menjadi lebih baik.

Sebuah kesadaran etik sangat penting dalam kehidupan masyarakat, sehingga menjadi penting pula untuk dibahas di dalam tulisan ini. Secara praktis, pembahasan di sini tidak disusun untuk membuat aturan verbal dalam bentuk undang-undang yang mengatur kehidupan masyarakat, tetapi dibuat untuk menggali sebuah nilai-nilai keutamaan yang tercermin di dalam sejarah dakwah Walisongo. Nilai-nilai keutamaan itu berupa etika universal yang

\footnotetext{
${ }^{1}$ Ubaidillah Achmad, "Epilog: Agama di Balik Fakta Politik", dalam Negara Islam Menurut Konsep Ibn Khaldun (Yogyakarta: Gama Media, 2007), 205.
} 
selama sejarah Walisongo telah berhasil efektif mempengaruhi perubahan atau transformasi sosial masyarakat. Adanya pengaruh prinsip etika yang diperkenalkan Walisongo ini benar-benar mampu mempengaruhi kesadaran masyarakat dan mewarnai setiap peraturan atau kebijakan yang dikeluarkan para penguasa kerajaan. Bahkan, nilai keutamaan yang diperkenalkan Walisongo, berupa prinsip etika, benar-benar menjadi barometer kebenaran yang bisa diterima masyarakat.

Dengan dasar prinsip etika yang ditekankan para Walisongo inilah kemudian menjadi lebih memudahkan Walisongo untuk bisa diterima dan bebas mengembangkan aspek normativitasnya di tengah kekuasaan raja. Selain itu, tata cara yang digunakan telah mempengaruhi pola dampingan serta pencerahan Walisongo yang diberikan kepada masyarakat. Dengan fenomena keberadaan transformasi Walisongo ini, kekuatan mereka adalah sebagai media berbagai kepentingan kedua belah pihak, antara masyarakat dan raja atau antara raja dan masyarakat. Kepentingan kedua belah pihak ini yang pada akhirnya mempercayakan keimanan seseorang kepada Walisongo di tengah upaya kedua belah pihak mendekatkan diri kepada kekuatan gaib yang mereka yakini jauh sebelum kedatangan para Walisongo. Momentum kepercayaan masyarakat dan penguasa kerajaan kepada Walisongo ini kemudian dimanfaatkan para Walisongo untuk menanamkan nilai fitrah yang sudah masuk dalam pemahaman dan keberagamaan Walisongo.

Sehubungan dengan yang berkembang di tengah-tengah keberagamaan umat Islam sekarang ini, sebenarnya problematika keberagaman dapat dipahami karena adanya kesalahan pola gerakan dari para tokoh keagamaan. Hal ini terjadi, bersamaan dengan kesadaran sikap masyarakat Indonesia yang berkecenderungan pada sikap paternalistik. Sikap paternalistik dalam kondisi apa pun akan memandang ketokohan seseorang. Karenanya, persoalan keagamaan yang mereka pahami sangat tergantung pada pola keberagamaan para tokoh yang mempengaruhi mereka. Ini artinya, sikap, dan perilaku para tokoh akan dipahami sebagai bentuk ajaran dari agama itu sendiri. Jadi, kerusakan keberagamaan masyarakat dengan didasarkan pada pola paternal masyarakat tidak dapat dilepaskan dari sikap ketokohan individu di tengahtengah masyarakat.

Oleh karena itu, munculnya krisis kepercayaan masyarakat terhadap simbol dan ajaran keagamaan, juga dapat dipahami hal tersebut tidak terlepas dari para tokoh agama yang semakin memperburuk citra agama, kurang mementingkan akhlak mulia, dan dalam konteks tertentu bersikap menghalalkan segala cara. Jika sikap yang demikian ini benar-benar terjadi, maka keberadaan agama tidak lagi dipahami sebagai jalan yang lurus dalam mempertahankan nilai kebenaran dan keutamaan. Hal yang tampak justru 
agama menjadi ajaran kepentingan para penguasa dan tokoh keagamaan. Dengan maraknya perkembangan keberagamaan yang cenderung tidak mengambil jalan tengah (ummatan wasatan), kehadiran tulisan ini menjadi sangat penting untuk memperkuat tanda dan bagaimana menandai keberagamaan yang berdasarkan etika universal dan ajaran Islam. Demikian ini, untuk menghindari problem terjadinya perkembangan agama yang berhenti hanya menjadi legitimasi kekuasaan. Dalam kondisi apa pun, umat Islam berkewajiban menjawab problem yang dapat menambah pemahaman yang strategis dalam meletakkan kepentingan agama sebagai agama pembebas atau menghindarkan agama dari kepentingan, baik yang bersifat personal maupun komunal.

Relevansi tulisan ini dengan problem tersebut untuk memperbaiki problem keberagamaan yang berkembang di tengah masyarakat sebagaimana yang pernah dicontohkan Walisongo di tengah lingkungan masyarakat Jawa, yaitu dengan mengedepankan prinsip etika universal yang dengan mudah ditemukan dalam ajaran Islam. Sedangkan, untuk lebih menspesifikasikan pembahasan dalam tulisan ini, tulisan ini akan diarahkan untuk menjawab tiga pertanyaan: Apa prinsip dasar etika universal Walisongo? Bagaimana keberagamaan Walisongo di tengah lingkungan masyarakat? Bagaimana relevansi keberagamaan Walisongo dengan keberagamaan sekarang ini?

\section{Kawasan Studi Walisongo}

Keberadaan Walisongo dapat dikategorikan sebagai keberadaan sejarah manusia. Dalam membaca sebuah sejarah manusia tergantung pada tolak ukur yang dipedomani. Jika Walisongo dipahami dari sejarah Islam sebelumnya, maka adanya Walisongo merupakan tanda keberlangsungan risalät al nubuwwah yang disampaikan Nabi Muhammad SAW. Artinya, keberadaan Walisongo merupakan bentuk keberlanjutan nilai keutamaan yang sudah dikenalkan para Nabi sampai pada Nabi Muhammad dan melalui para sahabat dan täbi' al-täbi'în dilangsungkan oleh para Walisongo. Namun demikian, tidak dapat dielakkan dalam sejarah umat Islam, telah ditemukan bebarapa konflik intern umat Islam sendiri, yang secara langsung berhubungan dengan sejarah kepemimpinan politik dan kekuasaan di tengah masyarakat. Berbeda dengan keberadaan Walisongo, pada masa Walisongo terjadi konflik yang tidak ditemukan berupa intern umat Islam dan intern keberagamaan di luar umat Islam. Konflik itu sering dialami antara kepentingan raja-raja Jawa dalam rangka mempertahankan sistem kekuasaan, sementara di sisi yang lain masyarakat menjadi korban relasi kekuasaan yang sangat feodalistikpaternalistik. 
Konflik-konflik di tengah lingkungan sistem kekuasaan raja-raja Jawa inilah yang mewarnai sejarah keberadaan Walisongo. Selain itu, pada masa ini juga berkembang aktivitas masyarakat yang sangat didominasi kepercayaan animisme dan dinamisme. Karenanya, keberagamaan Walisongo tidak dihadapkan pada perbedaan cara pemahaman terhadap ajaran Islam sendiri, tetapi benar-benar dihadapkan pada fenomena relasi kuasa yang tidak seimbang, baik yang ditimbulkan oleh penguasa kerajaan atau yang ditimbulkan oleh sistem kekuasaan masyarakat atas individu dan bentukbentuk kepercayaan animisme dan dinamisme. Jadi, perbedaan permasalahan yang dihadapi Nabi Muhammad dan Umat Islam sebelum Walisongo akan membawa dampak perbedaan strategi menjawab permasalahan. Perbedaan strategi dan jawaban persoalan keberagamaan Walisongo di tengah sistem kekuasaan penuh para raja ini pun (tentu saja) berbeda dengan strategi dan jawaban persoalan keberagamaan umat Islam di tengah sistem negara bangsa (nation state) yang menganut sistem trias politika (legislatif, yudikatif, dan eksekutif). Semua strategi dan jawaban yang berbeda dalam pola keberagamaan itu tidak boleh merubah kepercayaan yang penuh kepada Allah Swt dan kebenaran universal etika Islam yang sudah dibawa Nabi Muhammad dan Nabi sebelumnya. $^{2}$

Yang menjadi persoalan bukanlah terletak pada kualitas keberagamaan setiap umat sesuai dengan zamannya masing-masing, tetapi justru terletak pada ekses yang ditimbulkan pada setiap keberagamaan. Tulisan ini, merupakan hasil penelitian yang terkait dengan horizon teks Walisongo membangun demokratisasi keberagamaan individu di tengah zamannya. Alasan pentingnya menyampaikan hasil penelitian ini dalam satu tulisan utuh dan sistematis, karena telah banyak ditemukan hikmah keberagaman Walisongo yang didasarkan pada nilai ajaran Islam yang bisa dijadikan fondasi dasar bangunan pluralisme di tengah kompleksitas pemahaman masyarakat yang menganut sistem negara bangsa. Demikian ini karena pada zaman Walisongo telah mampu membuktikan kemampuanya membumisasikan Islam di tengah-tengah kuatnya pengaruh ajaran Hindu Budha dan kepercayaan animisme-dinamisme. Pribumisasi Walisongo ini mampu memberikan konstribusi pola transformasi agama di tengah problem yang dihadapi individu pada zamannya.

Sehubungan dengan fenomena hikmah transformasi keberagamaan yang disampaikanWalisongo tersebut, dapat dijadikan pedoman dalam upaya membangun kerangka berfikir positif di tengah maraknya berbagai macam kekerasan dan sistem kepercayaan masyarakat Indonesia dewasa ini. Yang

${ }^{2}$ Zidul Haque, Wahyu dan Revolusi, terj. E Setiawati al-Khattab (Yogyakarta: LKiS, 2000), $108-213$

92 | INDO-ISLAMIKA, Volume 1, Nomor 1, 2011/1432 
dimaksud dengan berfikir positip di tengah berbagai macam konflik dan kepercayaan adalah pentingnya upaya mengambil sikap positif dalam keberagamaan, sehingga akan terhindar dari pola keberagamaan yang menghalalkan segala bentuk kekerasan dan mempertentangkan perbedaan paham sampai pada mengorbankan nilai-nilai kemanusiaan. Transformasi keberagamaan yang disampaikan Walisongo ini dapat dijadikan upaya memperbaiki pola keberagamaan yang hanya dijadikan sebagai legitimasi kepentingan pribadi dan komunal.

Tulisan ini hendak mengupas nilai-nilai keutamaan yang dibawa Walisongo. Nilai-nilai keutamaan ini tidak terlepas dari prinsip etika yang selama ini mendasari transformasi Walisongo di tengah proses dampingan dan pemberdayaaan masyarakat. Secara metodologis, penelitian ini akan melacak semua yang terkait dengan tiga permasalahan utama dalam tulisan ini. Tujuan diajukannya ketiga pertanyaan ini untuk memperoleh pengertian yang mendalam mengenai situasi dan makna yang diteliti ${ }^{3}$ dengan perilaku subjek masyarakat. Hasil penelitian ini diperoleh dengan menggunakan data-data literer, sehingga meniscayakan metode sebuah metode pengumpulan data. Metode ini sesuai dengan upaya mencari dan belajar dari subyek penelitian (learning from people). ${ }^{4}$ Apa alasan mengambil subjek penelitian Walisongo?

Dengan didasarkan pada purposive sample, Walisongo merupakan subjek yang representat if dalam penelitian yang berhubungan dengan Islam Nusantara, karena Walisongo merupakan subjek atau pelaku transformasi dalam keragaman budaya dan kepercayaan masyarakat. ${ }^{5}$ Kesembilan wali yang menjadi subjek ini memiliki pengaruh yang sangat inspiratif bagi umat Islam dan masyarakat Jawa di tengah tatanan sistem negara bangsa. Dengan kata lain, sebelum peneliti melakukan penelitian tentang Walisongo sebagai subjek penelitian, masyarakat sudah mengenal dan mengamalkan ajaran Islam yang disampaikan oleh Walisongo, seperti keberagamaan dan nilai kebenaran pribumisasi Islam Walisongo. Namun demikian, supaya peneliti tidak jatuh pada wacana masyarakat yang cenderung romant is terhadap sejarah Walisongo, peneliti melakukan pengecekan terhadap data yang dapat dianggap memiliki otoritas pembahasan tentang Walisongo. Data-data tersebut berupa nilai

\footnotetext{
${ }^{3}$ Asmadi Alsa, Pendekatan Kuant itat if dan Kualitat if serta Kombinasinya dalam Penelitian Psikologi(Yogyakarta: Pustaka Pelajar, 2003), 55.

${ }^{4}$ A smadi Alsa, Pendekatan Kuant itatif, 55.

${ }^{5}$ Wali dalam bahasa In ggris pada umumnya diartikan dengan saint, sementara songo dalam bahasa Jawa berarti "sembilan". Walison go adalah tokoh-tokoh penyebar Islam di Jawa abad XVIXVI yang telah berhasil mengkombinasikan aspek sekular dan spiritual dalam memperkenalkan Islam pada masyarakat. Mereka secara bert urut -t urut adalah Maulana Malik Ibrahim, Sunan Ampel, Sunan Bonang, Sunan Kalijaga, Sunan Drajat, Sunan Giri, Sunan Kudus, Sunan Muria, dan Sunan Gunung Jati. Abdurrahman Mas'ud, Dari Haramain Ke Nusantara: Jejak Intelektual Arsitek Pesantren (Jakarta: Kencana, 2006), 57.
} 
keutamaan lokal yang bersumber dari pribumisasi Walisongo maupun yang secara langsung bersumber dari ajaran Islam (Quran, Hadis, Ijmak dan qiyass al'ulama) yang peneliti ambil dari referensi data tertulis (daftar pustaka). Pola pendekatan seperti ini, penulis dukung dengan cara audit trial, yaitu dengan mempertimbangkan masukan dan sumber yang sudah diterima.

Sedangkan, pentingnya daftar pustaka dalam penelitian ini lebih diarahkan untuk memperkuat sumber teorit is yang berkaitan dengan Walisongo sebagai subjek penelitian. Karenanya, sehubungan dengan etika universal Walisongo, peneliti potret sesuai dengan realitas sosial dengan kerangka teorit is yang penulis dapatkan dari metode kepustakaan. ${ }^{6}$ Dari metode ini akan memudahkan peneliti merumuskan fenomena keberadaan sejarah transformasi agama yang dilakukan oleh Walisongo. Dengan demikian, akan memudahkan peneliti melakukan interpretasi dan analisis terhadap objek penelitian. Sebagaimana dalam setiap penelitian akademik yang mentradisikan penggunaan kategorisasi sebuah sumber penelitian, penelitian ini (juga) menggunakan dua sumber.

Pertama, sumber primer yang berupa data tentang Walisongo dan literat ur yang membahas tentang karakter keberagamaan individu di tengah budaya lokal yang sezaman dengan Walisongo. Terkait dengan sumber primer ini, peneliti melakukan pembacaan secara hermeneutik sampai pada kontekstualisasi keberadaan teks dengan fenomena keberagamaan dalam masyarakat yang menganut sistem negara bangsa. Bersamaan dengan pola pembacaan secara hermeneutika ini, penulis melakukan sebagaimana yang disarankan Ranjit Kumar, yaitu melihat dan mendengarkan suatu fenomena perilaku subjek yang kemudian membuat suatu konklusi darinya, ${ }^{7}$ baik perilaku yang tertulis maupun perilaku yang masih dalam wacana sosial keagamaan. Kedua, sumber sekunder peneliti ambil dari literatur dan fenomena sosial kegamaan yang diasumsikan kuat bersumber dari Walisongo. Namun sumber sekunder ini tidak akan peneliti ambil sebelum memverifikasi kebenarannya dengan sumber primer.

Meskipun demikian, dalam upaya memperkuat data dan analisa, peneliti telah melakukan wawancara menggunakan pertanyaan terbuka, how, what, why, karena karakter dan respon individu berbeda terkait dengan Walisongo, maka struktur pertanyaan telah dikemukakan secara berbeda. Informasi yang digali dalam wawancara adalah sikap keberagamaan subjek di tengah lingkungan masyarakat. Keseluruhan data yang telah didapatkan ini, telah

\footnotetext{
${ }^{6}$ Veeger K.J., Realitas Sosial: Refleksi Filsafat Sosial at as Hubungan Individu-Masyarakat dalam Cakrawala Sejarah Sosiologi (Jakarta: Gramedia, 1993).

${ }^{7}$ Ranjit Kumar, Research Methodology, A Step-By-Step Guide for Beginners (London: SAGE Publications, 1999), 106.
} 
dilaporkan dalam tulisan ini, namun keseluruhan relasi makna dan interpretasi yang mendom inasi dalam tulisan ini tidak terlepas dari hasil perspekt if penulis. Dengan kata lain, selama menganalisa data, peneliti telah mereduksi dan memverifikasinya secara subjekt if dengan tidak meninggalkan objektifitas data yang sudah masuk dalam penelitian ini. Dalam konteks ini, peneliti diingat kan oleh Berten, bahwa keberadaan sejarah sastra tanpa keterlibatan interpretasi seorang pembaca tidak akan memunculkan makna. ${ }^{8}$

\section{Etika Universal Walisongo: Sebuah Perspektif}

Sehubungan dengan penelitian ini, peneliti menemukan sebuah kesimpulan mendasar, yaitu tentang keberadaan Walisongo sebagai sebuah teks itu sendiri. Sebagai sebuah teks tidak hanya dapat dipahami dari pesan yang bisa ditangkap dari teks, tetapi ia juga bisa menyimpan makna yang bisa dikembangkan oleh kesan pembaca. Makna teks yang bisa dikembangkan ini biasanya memiliki relasi dengan makna dan kesadaran yang lain. Relasi makna seperti ini yang sering mengingatkan subjek terhadap makna yang pernah berkembang di tengah masyarakat atau yang sering melahirkan makna baru yang belum pernah berkembang dalam perspekt if subjek. Secara filosofis, tidak hanya sebuah teks yang bisa melahirkan makna baru dalam perspektif subjek, tetapi sebuah kata pun akan bisa dipahami dengan baik oleh subjek karena adanya relasi makna yang bisa ditarik dari sebuah kata.

Oleh karena itu, penelitian yang mencoba mengembangkan makna relasional antara teks dengan makna kontekstual tidak bisa dikategorikan dalam sebuah penelitian yang bersifat mengada-ngada. Pola studi seperti inilah yang memperkuat pentingnya kajian hermeneutika dalam sastra dan sejarah pemikiran. Jadi, sebagai sebuah teks yang berkembang di tengah kehidupan masyarakat, keberadaan teks Walisongo bisa dipahami akan memungkinkan melahirkan interpretasi dan penilaian dari masyarakat secara berbeda-beda. Inilah alasan akademik, mengapa makna yang dapat ditangkap dari penelitian ini tidak hanya dari data kepustakaan saja, namun juga dari prinsip nilai keutamaan yang sudah turun-temurun yang telah dipedomani masyarakat terkait dengan sejarah pemikiran dan transformasi agama masa kewalian (Walisongo) di Jawa. Demikian ini, telah dibuktikan, bahwa makna terdalam dari keberagamaan Walisongo tidak hanya bisa diakses dari data kepustakaan, tetapi juga bisa diakses dari pemahaman yang sudah turun-temurun dari para peziarah Walisongo. ${ }^{9}$

\footnotetext{
${ }^{8}$ K. Berten, Filsafat Barat Abad XX Inggris-Jerman (Jakarta :Gramedia, 1983), 228.

${ }^{9}$ Yuliyatun, "Teori Modeling Psikologi Kepribadian: Studi Peziarah Walisongo dalam Pengemban gan Kepribadian”, Tesis, PPs KTTI Kajian Islam dan Psikologi UI Jakarta, 2007.
} 
Karena sudah banyak pembahasan mengenai profil Walisongo, maka tulisan dari penelitian ini akan memfokuskan spesifikasi pada pembahasan horizon teks Walisongo membangun demokratisasi keberagamaan individu di tengah zamannya. Cakrawala (horizon) teks Walisongo yang sangat mendasar adalah terkait dengan etika universal yang menjadi dasar transformasi agama di tengah masyarakatnya. Corak karakteristik masyarakat pada zaman Walisongo ini lebih mengutamakan kultur feodalisme relasinya dengan kekuasaan seorang raja dan lebih mengutamakan animisme dan dinamisme. Secara filosofis, keberadaan horizon teks Walisongo ini ditandai dengan berkembangluasnya relasi makna yang bersumber dari teks Walisongo. Kelayakan teks Walisongo menjadi sebuah teks keberagamaan didasarkan pada alasan karena ia telah memuat interpretasi kode dan "saluran" nilai keutamaan yang bisa berkembang menjadi interpretasi baru. Contoh, di tengah lingkungan masyarakat Jawa, teks Walisongo dipahami sebagai tanda kehidupan yang berisi pesan moral dan pengetahuan yang dapat dimaknai dan dikembangkan oleh para pembaca.

Ini artinya, keberadaan teks Walisongo sudah menjadi sumber keberagamaan dan sumber nilai keutamaan atau sumber etika dalam masyarakat. Selain itu, teks Walisongo dapat dijadikan simbol yang dapat memahamkan pembaca terhadap peristiwa yang sudah berlalu dan yang akan terjadi terkait dengan tema pergerakan yang sama, misalnya sama-sama terkait dengan transformasi agama di tengah masyarakat sosial. Meskipun demikian, sebagai tanda yang memuat pengetahuan, Walisongo tidak mudah dipahami setiap pembaca, bahkan (bisa saja terjadi) pembaca akan mengalami kemungkinan salah tafsir terhadap keberadaannya. Terjadinya salah tafsir ini rata-rata disebabkan adanya keinginan atau kecenderungan menempatkan Walisongo sebagai teks yang keluar dari normativitas teks Quran dan Hadis atau Walisongo ditempatkan sebagai teks sinkretisme yang mengisi perkembangan Islam. Munculnya salah tafsir ini akan selalu terjadi pada penafsiran-penafsiran yang lain dalam sejarah pemikiran. Namun demikian, bukan berarti banyaknya salah tafsir dalam sebuah interpretasi akan menutup kemungkinan munculnya penafsiran yang lebih mendekati pada kebenaran yang dimaksudkan teks. Karenanya, kebenaran penafsiran bisa dipahami dari kekuatan relasi makna yang dikandung teks dengan konteks fenomena sosial yang berkembang pada zamannya dan zaman baru yang memaknainya.

Namun demikian, semua pemahaman yang dikeluarkan dari teks Walisongo tentang keberagamaan tidak akan terlepas dari embrio relativitas ilmu pengetahuan. Meskipun keberagamaan seseorang didasarkan pada normativitas teks, namun pemahaman seseorang terhadap teks itu sendiri tetap masuk dalam kawasan historis. Ketika sudah masuk dalam kawasan historis, maka ia sudah sangat relatif dan tidak dapat dilepaskan dari masing-masing 
perspektif individu. Dengan demikian, prinsip keberadaan teks Walisongo ini dapat dipahami dengan menggunakan pendekatan hermeneutika. ${ }^{10}$ Bobot pemahaman hermeneutik ini, dalam pemahaman Richard E. Palmer memiliki enam tahapan bobot pengertian: hermeneutik sebagai teori penafsiran kitab suci, hermeneutik sebagai metodologi filologi, hermeneutik sebagai ilmu pemahaman linguistik, hermeneutik sebagai fondasi metodologis geisteswissenschaften (ilmu-ilmu kemanusiaan), dan hermeneutik sebagai fenomenologi desain dan pemahaman eksistensial. ${ }^{11}$

Dalam konteks kesejarahan, teks Walisongo memiliki cabang ilmu-ilmu kemanusiaan dan pola pemahaman eksistensial yang bisa diambil dari sistem pembebasan sejarah keberagamaan. Karenanya, dalam konteks historis Walisongo, bisa diajukan sebuah pertanyaan: bagaimana hubungan Walisongo dengan nilai kemanusiaan yang pernah berkembang di tanah Jawa? Bagaimana Walisongo mempengaruhi kepribadian eksistensial keberagamaan individu dan masyarakat? Bagaimana transformasi kemanusiaan Walisongo mempengaruhi eksistensi individu dan masyarakat? Inti dari kawasan studi Walisongo, adalah adanya meaningful sense (makna yang melampaui makna harfiah-literalyang dalam konteks tertentu bisa mengubah arti literal tersebut) yang terlahir dari keberagamaan Walisongo yang melahirkan makna eksistensial karakteristik keberagamaan individu dan makna eksistensi kultur masyarakat.

Perspektif Walisongo dapat dipahami dari struktur tiga serangkai yang saling terkait teori hermeneutika: pertama, pesan, tanda atau teks. Kedua, penafsir atau mediator. Ketiga, audience. ${ }^{12}$ Struktur tiga serangkai ini dapat dipahami melalui tiga aktivitas eksistensi manusia: kemampuan memahami, kemampuan menjelaskan atau menguraikan makna tersirat menjadi makna tersurat, dan kemampuan menerapkan atau mengkaitkan makna suatu teks dengan situasi baru dan kini. ${ }^{13}$ Walisongo pada zamannya dengan didasarkan pada data yang terhimpun dari sejarah transformasi agama yang dilakukannya, benar-benar sudah dapat dinilai telah memiliki tiga kemampuan tersebut: pertama, kemampuan bagaimana membaca pemahaman sejarah (historical

\footnotetext{
${ }^{10}$ Pada awal kemunculannya, hermeneutika dipakai untuk menafsirkan teks alkitab dan teksteks filsafat. Hermeneutika berasal dari akar kata: hermeneutikos, yang berarti "mengartikan, menginterpretasikan, menafsirkan, menerjemahkan." Abad ke-17 dan 18 istilah ini diartikan sebagai "ajaran tentang kaidah-kaidah yang digunakan untuk memahami dan menafsirkan secara tepat naskah teks dari masa lampau (theory of scriptural exegesis), khususnya kitab suci dan teks klasik." Lorens Bagus, Kamus Filsafat (Jakarta: Gramedia, 2000), 284; Richard E. Palmer, Hermeneutics; Interpretation Theory in Schleiermacher, Dilthey, Heidegger, and Gadamer (Evanston: Northwestern University Press, 1969), 34.

${ }^{11}$ Richard E. Palmer, Hermeneutics; Interpretation Theory in Schleiermacher, Dilthey, Heidegger, and Gadamer, 34.

${ }^{12} \mathrm{~V}$ an A Harvey, "Hermeneut ic", dalam Marcea Eliade, The Encyclopedia of Religions (New York: Mac Milan Publish ing Co), Vol. 6, 279.

${ }^{13}$ E. Sumaryono, Hermeneut ik, Sebuah Metode Filsafat (Yogyakarta: Kan isius, 1993), 76.
} 
understanding) dan kesadaran sejarah (historical consciousness) t erhadap Islam. Kedua, kemampuan menjelaskan makna keberagamaan yang lebih transformatif. Ketiga, kemampuan menerapkan suatu teks normatif agama Islam dalam situasi yang dihadapi pada zamannya.

Jika Walisongo memiliki perspektif transformasi yang berbeda dengan awal sejarah Islam, kini keberadaan perspektif Walisongo dapat dimaknai kembali berbeda dengan perspekt if Walisongo. Dalam penelitian in i ditemukan, bahwa secara substansial prinsip etika universal yang menjadi dasar transformasi Walisongo sama dengan dasar transformatif nubuwwah. Perbedaannya hanya terletak pada konteks kesejarahan yang dihadapi masingmasing zaman yang berbeda. Salah satu contoh, pada masa Nabi Muhammad konteks kesejarahannya menghadapi kekuatan sastra yang berkualitas sangat tinggi dan peradaban jahiliah yang menghalalkan semua yang menjadi kebutuhan nafsu keserakahan dan hegemonik, sementara itu pada masa Walisongo menghadapi kekuatan sistem kerajaan dan kultur masyarakat yang sangat feodalistik-paternalistik. Kini, zaman Walisongo sudah tidak dijumpai lagi. Para pembaca tentang sejarah Walisongo sekarang ini telah dihadapkan pada sistem negara bangsa (nation state) dan liberalisasi ekonomi dunia dan pemahaman keagamaan.

Karenanya, tugas pembaca terhadap keberadaan Walisongo, meminjam Carl Braaten, harus memiliki kemampuan memahami dan mengeksiskan teks dalam konteks situasi masa kini. ${ }^{14}$ Pembaca harus memiliki kemampuan menangkap proses dialektik antara teks dan peradaban ('urf atau 'ádah) relevansinya dengan konteks yang dihadapi Walisongo. Pembaca dalam teori hermeneutika harus mampu mengisi pemahaman dengan keutamaan yang ditemukan dari pengalamannya. Artinya, pembaca Walisongo harus mampu mengungkapkan eksistensi dirinya sendiri tentang nilai keutamaan prinsip etika universal $^{15}$ dan horizon teks yang dibacanya. Dalam mengungkapkan horizon teks Walisongo dapat dipahami melalui objective meaning (makna teks yang sebenarnya) dan significance atau relevance (terapan makna ke dalam konteks at au tempat lingkungan teks berada).

Kini, significance teks Walisongo dari hasil penelitian ini dapat digunakan untuk menjawab dua persoalan: pertama, formalitas yang dihubungkan antara struktur agama dan ajaran agama. Kedua, problem kehidupan masyarakat agam is menghadapi isu sekularisme, pluralisme dan liberalisme. Dua persoalan ini menjadi pertentangan kelompok Islam berbasis organisasi keagamaan, Islam

\footnotetext{
${ }^{14}$ Carl Braaten, History and Hermeneutics (Philadelphia : Fortress, 1966), 131.

${ }^{15}$ Wasito Poespoprojo, "Hermeneutik Filsafati Relevansi Dari Beberapa Perspektifnya Bagi Kebudayaan Indonesia," disertasi, Universitas Padjadjaran, Bandung, 1985, 70.
} 
Liberal, Islam Salafi, Islam Kesejahteraan, Islam Persatuan, Islam Kebangsaan dan Islam Politik. Menjawab dua persoalan tersebut, teks Walisongo tidak banyak membicarakan normativitas teks (nașs) dari ajaran Islam sebagaimana yang ditetapkan dalam Quran, hadis, ijmak, dan qiyās. Berdasarkan keseluruhan data kepustakaan dan pemahaman keagamaan yang berasal dari Walisongo, menegaskan pola transformasi Walisongo yang didasarkan pada nilai keutamaan etika universal.

Jadi, peneliti belum menemukan data keberadaan gerakan Walisongo lebih pada upaya menyembunyikan kepentingan politik golongan dan mengedepankan formalitas antara struktur agama dan ajaran agama. Sebaliknya, transformasi keagamaan yang dilakukan Walisongo lebih menekankan pada aspek kultural, seperti isu kemanusiaan, demokratisasi, pemberdayaan masyarakat, dan penguatan ekonomi rakyat. Jadi, di tengah relasi kuasa, Walisongo lebih berupaya mencari kawan dalam struktur itu sendiri secara lebih simultan, kultural, dan evolusioner. Pola gerakan seperti ini merupakan bentuk gerakan pembebasan yang tanpa dasar apapun, kecuali kualitas eksistensi manusia. Peran agama berfungsi sebagai suplementer atau penyedia "sarana" proses perubahan. Demikian ini sejalan dengan fungsi agama, yaitu tidak bisa membuat sebuah perubahan. Karena, dalam pandangan Abdurrahman Wahid, dunia itu akan berkembang sesuai dengan pertimbangan "dunianya" sendiri. Agama hanya mempengaruhi sejauh dunia itu siap dipengaruhi, tidak lebih dari itu. Begitu agama mengubah dirinya menjadi penentu, tidak lagi hanya mempengaruhi tetapi menentukan, maka dia telah menjadi duniawi. Jika agama dijadikan sebagai penentu perubahan, maka yang akan terjadi adalah sikap represif. Agama menjadi represif untuk mempertahankan dirinya. Karenanya, proses pembebasan harus tetap diserahkan kepada rakyat. Dalam konteks relasinya dengan kekuasaan, rakyat harus didorong untuk memikirkan paradigmanya sendiri. ${ }^{16}$

Dari prinsip ajaran agama tersebut, dapat dipahami, bahwa keberadaan agama tidak mengajarkan otoritas surga mampu memperebutkan sistem kekuasaan, tetapi justru lebih menekankan sebuah sistem itu bisa berjalan sesuai dengan dasar tauhid. Secara logis, istilah tauhid memberikan pengertian, bahwa penciptaan Tuhan adalah Esa. Dia menolak segala bentuk diskriminasi berdasarkan ras, warna kulit, kelas, garis keturunan, kekayaan, dan kekuasaan. Dia menempatkan manusia dalam kesamaan. Dia juga menyatukan antara manusia dan alam yang melengkapi penciptaan Tuhan. Ke-Esa-an Tuhan berarti keesaan kehidupan, yakni tidak ada pemisahan antara keagamaan, dan

\footnotetext{
${ }^{16}$ Abdurrahman Wahid, "Jangan Paksakan Paradigma Luar Terhadap Agama," dalam Muh. Shaleh Isre, ed., Prisma Pemikiran Gus Dur (Yogyakarta: LKiS, 2000), 167-169.
} 
keduniawian. Dengan memahami seluruh aspek kehidupan diatur oleh satu hukum dan tujuan seluruh Muslim yang bersatu dalam kehendak Allah ${ }^{17}$ yang dirangkai dengan nilai keutamaan sebuah kebenaran.

Sejarah peradaban Islam, dalam catat an historis Wahid, telah memberikan pelajaran kepada kita tentang kelembagaan agama. Betapa hebatnya sebuah agama sekali pun, pendiriannya tidaklah mengajarkan orang mencintai kelembagaan apa pun. Yang disampaikan adalah kebenaran, yang dalam Islam berupa tauhid (ajaran tentang keesaan Tuhan dan keutusan Muhammad SAW). Atas dasar itu, segala macam institusi yang mengatasnamakan Islam sebenarnya hanya bersifat perkiraan (ijtihad) belaka."18 Relasi teks agama dengan sistem kekuasaan lebih menekankan agar para penguasa tidak sewenang-wenang dalam mengendalikan kekuasaannya. Sebab, bagi Gus Dur, pusat-pusat kekuasaan itu tidak berdiri sendiri. Di luar pusat kekuasaan itu masih terdapat berbagai kelompok masyarakat yang besar. Peran mereka selalu harus diperhitungkan dalam kehidupan kenegaraan. Dari kelompok minimal harus dimintakan dukungan setiap saat. Proses kenegaraan tampaknya tetap berlangsung di luar pusat kekuasaan formal. Kelompok di luar ini bukanlah pusat kekuasaan melainkan pusat pemberi legitimasi kepada pusat kekuasaan. ${ }^{19}$

Significance atau relevance konsep kewalian Walisongo, dalam konteks relasinya dengan sistem kekuasaan atau jabatan publik, memiliki makna yang bisa dipahami berbeda dengan konsep awal dari kewalian sendiri di Timur Tengah. Secara sosiologis Abdurrahman Wahid menggambarkan, bahwa konsep kewalian di Timur Tengah lebih menunjukkan kepada orang saleh dan suci yang menolak keduniawian dan larut dalam perilaku kefanaan diri (tafannī). Sementara itu, konsep kewalian orang-orang Indonesia (atau lebih tepatnya lagi, orang Jawa) tetap mempertahankan fungsi-fungsi keduniawian tertentu bagi orang-orang suci tadi, di mana banyak dari mereka adalah orang yang piawai dalam berbagai jabatan publik, yang kemudian tetap dipakai sebagai para penasihat oleh para raja dan adipati. ${ }^{20}$

Strategi gerakan yang didasarkan pada universal etika Islam ini, memiliki dasar yang sangat kuat sebagai bentuk potensi yang sudah dimiliki manusia. Dasar potensi etika universal ini, dalam kajian tasawuf, sudah berada dan terbentuk dalam potensi fitrah. ${ }^{21}$ Fitrah ini pula yang telah dijadikan sumber

${ }^{17}$ Kazuo, Shimogaki, Kiri Islam, terj. M. Imam Aziz dan Jadul Maula (Yogyakarta: LKiS, 1997), 19.

${ }^{18}$ Abdurrahman Wahid, "Agama: Antara Keyakinan dan Kelembagaan," dalam Hairus Salim HS, ed., Menggerakkan Tradisi (Yogyakarta: LKiS, 2001), 24.

${ }^{19}$ Abdurrahman Wahid, "Persaingan di Bawah Justru lebih Hebat," 190.

${ }^{20}$ Abdurrahman Wahid, "Prinsip-Prinsip Pendidikan Pesantren," 177.

${ }^{21}$ Ubaidillah Achmad, "Fitrah dan Potensi Insani dalam Ilmu Tasawuf", dalam Jurnal Konseling Religi, ST AIN Kudus, Vol. 1, Nomor 1 (2010), 1-38. 
prinsip etika universal Walisongo. Dari hasil penelitian yang dilakukan Ubaidillah, secara etimologis, fitrah berasal dari akar kata fatara, berarti: membuka, menguak dan menggali. Sedangkan secara terminologis, fitrah sering dipahami sebagai bentuk potensi dasar yang memiliki relasi makna dengan kesadaran tauhid atau nilai-nilai ketuhanan (fitrah ilahiyyah). Selain itu, fitrah sering dipahami sebagai bentuk potensi dasar yang memiliki relasi makna dengan kesadaran pentingnya nilai-nilai kemanusiaan (fïtrah insāniyyah). Sejak asal mula kejadian manusia, kesadaran tauhid atau nilai ketuhanan ini sering diasumsikan sebagai potensi dasar yang sudah berada bersamaan dengan kesadaran pentingnya nilai kemanusiaan. Karenanya, kembali ke fitrah berarti kembali pada potensi dasar yang sudah berada sejak asal mula kejadian manusia (QS. al-Rūm [30]: 30). Jadi, fitrah merupakan potensi nilai yang tinggi dan luhur (fitrah ilăhiyyah dan insäniyyah) yang sudah dimiliki manusia sejak awal penciptaannya. $^{22}$

Sehubungan dengan keberadaan fitrah ini, dari hasil penelitian Ubaidillah, manusia akan dihadapkan pada lingkungan yang berpotensi mempengaruhi dan membentuk perilaku individu menjadi lebih buruk. Ini artinya, potensi fitrah yang ahistoris tersebut akan dihadapkan pada lingkungan yang historis yang memungkinkan baik dan buruk. Karenanya, Murthada Mutahhari menganalogikan fitrah dengan sebatang tumbuhan. Sebatang tumbuhan itu sangat memerlukan cahaya, air, dan lain sebagainya. ${ }^{23} \mathrm{Jadi}$, potensi fitrah akan berkembang dengan baik apabila berada dalam lingkungan yang baik dan kondusif untuk pengembangan potensi fitrah (muktasab), namun juga sebaliknya. Untuk itu, potensi fitrah sangat membutuhkan metode yang dapat memberikan penguatan dalam diri setiap individu. Metode yang dapat memberikan penguatan ini pun masih terkait dengan potensi insani yang sebenarnya juga telah dianugerahkan kepada setiap individu, yaitu 'aql. Dengan menggunakan 'aql akan muncul: potensi menalar (al-fițrah al-'idrákiyyah) dan potensi merasa (al-fịtrah al-'iḥsāsiyyah). ${ }^{24}$

Kesadaran fitrah inilah yang mendasari (basic identity) bangunan prinsip etika universal dalam sejarah keberagamaan Walisongo: bagaimana Walisongo melakukan interaksi dengan individu dan masyarakat? Dalam catatan sejarah Islam di tanah Jawa disebut kan, bahwa pada masa Walisongo telah berlangsung keutamaan budaya lokal. Model seperti inilah yang menjadi titik dasar pengembangan dan pelestarian budaya lokal. Tradisi lokal yang terkait dengan keberadaan budaya masyarakat Jawa sudah lama menjadi bagian penting

\footnotetext{
${ }^{22}$ Ubaidillah Achmad, "Fitrah dan Potensi Insani dalam Ilmu Tasawuf," 138.

${ }^{23}$ Ubaidillah Achmad, "Fitrah dan Potensi Instani dalam Ilmu Tasawuf," 298.

${ }^{24}$ Ubaidillah Achmad, "Fitrah dan Potensi Instani dalam Ilmu Tasawuf," 138.
} 
filosofi Jawa dan menjadi bagian penting proses terjadinya penggabungan antara unsur nilai Islam dan banyak unsur non-Islam sebagai bentuk dari persoalan pendekatan dan kebijaksanaan (The Walis incorporation of many non-Islamic elements is a matter of approach and wisdom. The latter is absolutely needed in any Islamic transmission. $)^{25}$

Demikian ini dapat dibaca dalam catatan sejarah Jawa, misalnya Serat Dewi Ruci sebagai salah satu lakon wayang, yang pada hakikatnya mengibaratkan usaha ke arah tarekat, hakikat dan makrifat. Inilah lakon yang menggambarkan sang Bhima atau Arya Sena mencari Air Suci Perwita Sari Kayugung Susuhing Angin (Air Suci Perwita Sari, kayu besar sarang nafsu), yang akan dipersembahkan kepada Pandita Durna sebagai syarat-syarat agar pendeta ini mau memberikan wejangan tentang Ngelmu Jatining Jejer ing Pangeran at au hakikat kedudukan (maqām) Tuhan. Dalam lakon ini sang Bhima yang melambangkan seorang salik (ahli tarekat) dalam perjalanan tarekat dan suluknya untuk mencapai makrifat telah menemui godaan batin dari nafsunafsu di dalam diri sendiri. ${ }^{26}$

Contoh yang amat mengagumkan, keberhasilan Sultan Agung mengubah dan mengislamkan perhitungan Tahun Saka tanpa meniadakan unsur-unsur dan ciri kejawennya yang melahirkan tahun Jawa baru. Tahun Jawa Sultan Agung ini cukup memuaskan dan persis seperti Tahun Hijriyah, hanya tahun satunya tetap sama satu Saka, dan unsur-unsur Jawa yang berkaitan dengan perhitungan ilmu klenik masih dipertahankan. Tidak pelak lagi bahwa politik klenik masih dipertahankan. ${ }^{27}$ Bentuk tradisi budaya ini memang tidak murni keislamannya, namun merupakan wasilah yang efektif untuk membuka hati para pecinta seni budaya Jawa kepada agama Islam. Para pujangga dan sastrawan serta budayawan Jawa ternyata amat berbakat untuk menggubah unsur-unsur Islam pesantren seperti kepercayaan kepada wali keramat, menjadi pemitosan tentang "Walisango" sebagai pelindung masyarakat dan raja-raja Jawa Islam. ${ }^{28}$

Karena dalam realitas transformasi Walisongo meniscayakan prinsipprinsp keseimbangan, maka keberadaannya menetapkan penolakan kekuasaan masyarakat atas individu menuju suatu suasana di mana arah individu akan memungkinkan tegaknya al-kulliyah al-khamsah (lima jaminan dasar): jaminan dasar at as keselamatan keyakinan, keselamatan fisik, kesucian keluarga, harta milik, dan jaminan at as keselamatan profesi. Hal ini didasarkan pada sebuah

\footnotetext{
${ }^{25}$ Abdurrahman Mas'ud, The Pesantren Architecs and Their Socio-Relegious Teachings (1850-1950) (Los An geles: UMI, 1997), 50.

${ }^{20}$ Widji Saksono, Mengislamkan Tanah Jawa: Telaah atas Metode Dakwah Walisongo (Bandung: Mizan, 1995), 147.

${ }^{27}$ Simuh, Sufisme Jawa: Transformasi Tasawuf Islam ke Mistik Jawa (Yogyakarta: Yayasan Bint ang Budaya, 1995), 20-21.

${ }^{28}$ Simuh, Sufisme Jawa, 20-21.
} 
kaidah tasartuf al-imām manūtun bi al-maslahah (kebijaksanaan pemegang kekuasaan dalam kaitannya dengan rakyat mestilah bertujuan meningkatkan kemaslahatan mereka). Kaidah al-kulliyah al-khamsah tersebut merupakan bentuk pengajaran dari format transformasi sosial sebuah agama.

Sehubungan dengan prinsip tersebut di atas, dalam pandangan Wahid, harus dimulai dari transformasi intern agama. Karena sebuah transformasi ekstern yang tidak bertumpu pada transformasi intern di lingkungan lembaga atau kelompok keagamaan it $u$ hanya akan menjadi transformasi yang dangkal. Untuk dapat melakukan transformasi intern itu, agama harus merumuskan kembali pandangannya mengenai martabat manusia, kesejajaran kedudukan semua manusia di muka undang-undang dan solidaritas hakiki antara sesama umat manusia. Melalui upaya ini, setiap agama dapat berintegrasi dengan keyakinan-keyakinan lain dalam bentuk pencapaian sejumlah nilai-nilai dasar universal yang akan mendudukkan hubungan antaragama pada sebuah tataran baru. Tataran baru itu adalah tahap pelayanan agama kepada warga masyarakat tanpa pandang bulu dalam bentuknya yang paling konkret, seperti penanggulangan kemiskinan, penegakan kedaulatan hukum, dan kebebasan menyatakan pendapat. Apabila sebuah agama telah memasuki tataran baru itu, barulah ia berfungsi melakukan pembebasan ( tahri $\bar{r} /$ liberation) ${ }^{29}$

Keseluruhan dari naskah ini benar-benar telah menegaskan adanya integrasi prinsip etika universal yang dikenalkan Walisongo dengan budaya lokal Jawa. Pola integrasi ini didasarkan pada rumusan jitu dalam konsep kegiatan sosial yang senantiasa harus bersandar pada prinsip tujuan dan cara penyampaiannya (al-ghāyah wa al-wasā'il). Ini artinya, selama tujuan (termasuk sasaran) masih tetap, cara penyampaian menjadi masalah sekunder. ${ }^{30}$ Demikian ini sudah berkembang sejak Walisongo di tengah keanekaragaman masyarakat dan tanpa ada penolakan dari raja-raja. Jadi, dapatlah dipahami bahwa pola keberagamaan Walisongo bersifat melengkapi budaya dan bukannya mempertentangkan Islam dengan budaya lokal. Walisongo telah menghasilkan taraf pembentukan kepribadian masyarakat yang berbudaya, yakni individu-individu yang memperlihat kan kearifan yang lebih tinggi dalam adaptabilitas yang menyeluruh untuk pengembangan kepribadian dan pola hubungan antar manusia yang dinamai pergaulan masyarakat. ${ }^{31}$

Masyarakat Jawa mengakui adanya aktifitas keberagamaan yang mereka jalankan sekarang ini, tidak dapat dilepaskan dari nilai Islam yang menjadi

\footnotetext{
${ }^{29}$ Abdurrahman Wahid, "Agama dan Demokrasi", dalam Seri Dian/Interfidei $2 /$ Tahun 1 (Yogyakarta: Interfidei, 1994), 272-273.

${ }^{30}$ Abdurrahman Wahid, "Islam dan Masyarakat Bangsa," dalam Kacung Marijan, ed., Mengurai Hubungan Agama dan Negara (Jakarta: Gramedia, 1999), 75.

${ }^{31}$ Abdurrahman Wahid, "Islam dan Masyarakat Bangsa," 74.
} 
prinsip Walisongo ini. ${ }^{32}$ Prinsip ini yang sampai sekarang masih sangat mengakar dalam kehidupan sosio-kultural dan religius masyarakat Jawa. Bahkan, bagi sebagian masyarakat Jawa menganggap keberadaan teks Walisongo menjadi the Religion of Java. Selain pentingnya potensi fitrah yang dijadikan Walisongo untuk membangun kepribadian individu dan masyarakat, Walisongo dalam menegakkan syariat lebih menekankan pada upaya mempotensikan kalbu dan akal. Demikian ini didasarkan pada keyakinannya, bahwa $q a l b$ merupakan kacamata hati yang dapat digunakan untuk memahami kebenaran fitrah manusia. Sedangkan, 'aql merupakan kaca mata berfikir yang dapat digunakan untuk membandingkan prinsip-prinsip yang termuat dalam fitrah perbandingannya dengan daya-daya negat if yang ditimbulkan dari dalam diri manusia melalui keinginan buruk atau negatif manusia (al-nafs al'ammarah bi al-sū').

Meskipun penegasan transformasi Walisongo difokuskan pada penggalian potensi individu melalui $q a l b$ dan $a q l$, namun tetap mendasarkannya dengan sumber Quran, hadis, dan hasil ijtihad para madzhab sebagaimana yang juga diakui dalam tradisi Nahdlatul Ulama. Mata rantai pola keberagamaan yang didasarkan pada pengalaman langsung (direct experience) Walisongo ini benarbenar lebih efektif mempengaruhi sikap keberagamaan Muslim Jawa hingga sekarang ini. Contoh seperti ini dapat dibuktikan dengan adanya jalinan emosional individu dan masyarakat yang sering mendatangi (ziarah) makam Walisongo. Karenanya, hampir setiap harinya makam-makam para Walisongo tidak lengang dari para pengunjung, baik yang berasal dari rumpun Jawa maupun yang berasal dari luar rumpun Jawa.

Para pengunjung di makam para Walisongo ini dari hasil pengamatan penulis semuanya memahami pentingnya integrasi antara nilai keutamaan prinsip etika universal dengan budaya lokal. Bahkan bisa diperhatikan melalui berita terbalik, baik melalui media cetak maupun elektronik, bahwa rata-rata para pengunjung makam Walisongo bukanlah sosok yang selalu mengedepankan sikap eksklusivitas atau fanatisme di tengah masyarakat dan lingkungannya. Terbukti pula, bagi mereka yang benar-benar berniat ziarah ke makam Walisongo tidak akan sependapat dengan sikap penolakan terhadap sikap Islam lokal khas Jawa. Pola keberagamaan peziarah makam Walisongo, juga memahami pola keberagamaan benar-benar dari potensi fitrah.

\footnotetext{
${ }^{32}$ Ubaidillah Achmad, "Pendidikan Multikultural Gagasan Walisongo Menuju Keutamaan Individu dan Budaya Lokal," dalam Jurnal Pendidikan Islam (Jakarta), Vol. IX No. 2 (2006), 178192.
} 
Karenanya, mereka justru menolak dengan pola keberagamaan yang hanya didasarkan pada keruntutan logika. ${ }^{33}$ Bahkan, para peziarah Walisongo lebih banyak diisi para jemaah yang tidak memperdulikan dasar-dasar keberagamaan mereka, apakah didasarkan pada nalar bayāní yang telah membesarkan disiplin fikih (hukum)? Apakah didasarkan pada nalar 'irfänì yang telah menghasilkan teori-teori besar? Tetapi, mereka meyakini keberagamaan yang baik adalah keberagamaan yang semakin mendekatkan diri kepada Allah Swt dengan cara berzikir memohon pertolongan serta ampunan kepada-Nya. Selain itu, keberagamaan yang baik adalah yang bersikap manusiawi antar intern agama dan sesama agama atau bahkan baik pula dengan mereka yang tidak mengakui adanya fitrah atau tidak mengakui adanya Allah SWT.

Dengan tanpa mereka pahami secara akademik, sebenarnya para peziarah makam Walisongo telah menemukan cara-cara atau praktik-praktik kesufian dalam upaya mendekatkan diri kepada Allah SWT, seperti: ilhām, kashf, damīr, dan wirid-wirid yang diajarkan dalam tarekat-tarekat. Namun demikian, kedatangan mereka ke makam Walisongo adalah bertujuan untuk mencari keharmonisan sikap baik yang ingin dirasakan untuk diri sendiri maupun keharmonisan sikap terhadap pihak yang lain. Keutamaan teks Walisongo menjadi sumber keutamaan et is dalam realitas kehidupan sosial. Berbeda dengan metode dan teori yang ditemukan dalam studi akademik seperti bayan $\bar{i}$, burhān $\bar{i}$ dan 'irfän $\overline{\text {, }}$, sejarah teks Walisongo berkembang menandai sikap prinsip etika universal dalam keberagamaan individu dan masyarakat dengan tanpa terikat dengan kerangka-kerangka teori yang rumit.

Keberadaan teks Walisongo merupakan kelangsungan dari tradisi nubuwwah. Karenanya, sangat relevan jika menempatkan kerangka transformasi yang dilakukan Walisongo sebagai kelanjutan dari kerangka transformasi Nabi Muhammad. Pola internalisasi Walisongo dengan budaya lokal, dapat ditemukan dengan mudah pada masa risalah kenabian Muhammad berlangsung. Ajaran fundamental pada masa Nabi Muhammad itu berupa keutamaan nilai religius dan melakukan pembaharuan sosial. Pembaharuan sosial itu lebih diarahkan pada penyempurnaan akhlak yang mulia ( $i i$ 'utammima makārim al-akhlāq) yang telah eksis di tengah masyarakat. Karenanya, ia tidak secara revolusioner merubah tatanan yang diskriminatif. Namun demikian, keberadaan risalah Muhammad selalu menandai adanya nilai keutamaan dalam kawasan studi akademik berikut ini: stat us kaum perempuan, pemerdekaan budak-budak (meski perbudakan sebagai sistem tidak dihapus), larangan pembunuhan bayi perempuan, penghargaan kebijakan yang dihormati

${ }^{33}$ M. Amin Abdullah, "Filsafat Islam Bukan Hanya Sejarah Pemikiran," dalam A. Khudori Soleh, Wacana Baru Filsafat Islam (Yogyakarta: Pustaka Pelajar, 2004), Ix. 
para pengikutnya yang dalam konteks tertentu menjadi sebuah aturan yang ditetapkannya. ${ }^{34}$

Secara antropologis, sebenarnya pola adaptabilitas yang menyeluruh ${ }^{35}$ Walisongo ini tidak bisa dihindarkan dari perkembangan kebudayaan manapun. Karenanya, dalam keberagamaan individu dan masyarakat sangat meniscayakan proses dinamisasi budaya. Demikian sesuai dengan penegasan Marshall Sahlins: "Ketika muncul tipe-tipe kebudayaan baru, tipe-tipe itu mengalami proses yang tak terelakkan berupa radiasi dan adaptasi terhadap lingkungan totalnya yang khas. Proses atau aspek ini sebagai evolusi spesifik (specific evolution)." ${ }^{36} \mathrm{Jadi}$, setiap budaya memiliki hubungan dengan nilai historis struktur masyarakatnya. Proses interaksi ini merupakan bentuk interaksi budaya masyarakat yang sudah maju saling terkait dalam satu kebutuhan memenuhi hajat hidup. Demikian ini, juga akan ditemukan dalam hubungan antarkasta, antarkelas masyarakat, antar kelompok profesi, ant arpartai.

Oleh karena itu, jika terjadi gangguan terhadap salah satu komunitas masyarakat, maka akan terjadi pula gangguan terhadap komunitas yang lainnya. Sebaliknya, ketenangan yang dirasakan salah satu komunitas, akan berdampak positif pada komunitas yang lainnya. Karenanya, interaksi Walisongo yang meyakini kebenaran nilai Islam dengan minat masyarakat Jawa merupakan bentuk hubungan dengan nilai historis struktur masyarakat yang akan mengalami evolusi spesifik (specific evolution). Dengan demikian, kebersamaan dalam kepribadian individu di tengah kehidupan masyarakat tidak mutlak perlu, namun yang niscaya dibutuhkan adalah perilaku pihak yang terlibat dalam interaksi itu dapat saling mengerti dan memahami satu sama lainnya.

Adaptabilitas yang menyeluruh Walisongo, merupakan bentuk pendekatan sosio-kultural Walisongo supaya lebih memahami masalah transformasi dengan tidak memaksakan kehendak pribadi atau komunal sendiri. Pendekatan pemaksaan yang akan mengarah pada kekerasan sebenarnya merupakan proses pelarian (escapism). Misalnya, sebagaimana dimuat dalam tulisan Abdurrahman Wahid, ketika umat Islam menuntut syarat yang terlalu idealistik untuk menjadi Muslim yang baik dengan tidak mengakui kemusliman orang yang tidak mampu memenuhi syarat itu, seperti: orang yang baru bisa

\footnotetext{
${ }^{34}$ Madjid Khaduri, Teologi Keadilan: Perspekt if Islam, terj. H. Mokhtar Zoerni dan Joko S. Kadir (Surabaya: Risalah Gust i, 1999), 12.

${ }^{35} \mathrm{M}$ arshall Sahlins menyebut proses atau aspek adaptabilitas yang menyeluruh ini, sebagai "evolusi umum" (general evolution). David Kaplan dan Albert A. Manners, Teori Budaya (Yogyakarta: Pustaka Pelajar, 1999), 66.

${ }^{36}$ David Kaplan dan Albert A. Manners, Teori Budaya (Yogyakarta: Pustaka Pelajar, 1999), 66.
} 
melaksanakan ibadah haji dan zakat sementara belum mampu melaksanakan shalat dan puasa dengan baik. Kecenderungan formalitas keagamaan justru akan menimbulkan kekeringan transformasi agama. ${ }^{37}$ Misalnya menyesuaikan budaya masyarakat dengan peraturan budaya yang sudah ditetapkan UU dan $\mathrm{PP}$, justru hanya akan mengakibatkan konflik horizontal yang mengganggu harmonisasi keberagamaan yang sudah dikenalkan oleh para Walisongo.

Dengan demikian, semua budaya masyarakat yang bertahan dan berkembang dalam sebuah sistem kehidupan mempunyai satu ikatan kehidupan yang sangat sulit dihilangkan. Dari teks Walisongo dapat dipetik bahwa budaya lokal merupakan media yang dapat dijadikan proses pribumisasi agama Islam. Pengembangan dan pelestarian budaya lokal yang sesuai dengan prinsip etika universal merupakan salah satu sikap keberagamaan yang manusiawi. Karenanya, kedatangan Walisongo di tanah Jawa benar-benar membuat kesulitan Martin Van Bruinessen dalam membuat kesimpulan: apakah adat yang berkembang di tengah-tengah masyarakat Nusantara sekarang ini telah mewakili kebiasaan pra Islam. ${ }^{38}$

Demikian ini terjadi, karena antara adat yang berkembang di tengahtengah masyarakat Nusantara sekarang ini dan kebiasaan pra Islam sudah sangat sulit dibedakan. Walisongo sendiri telah memberikan contoh Kerajaan Demak sebagai manifestasi pengakuan kebebasan dan perlindungan bagi pemeluk Hindu-Budha dan budaya lokal lainnya. Dalam konteks ini, Walisongo menampakkan keberagamaan yang humanis. Target keberadaan teks Walisongo di tanah Jawa pada abad ke 15 dan 16 yang lalu bukanlah simbolisasi agama, tetapi justru bagaimana memecahkan secara egaliter dan manusiawi problem masyarakat yang terasing. ${ }^{39}$ Dalam sistem kerajaan, para raja selalu meminta nasihat kepadanya agar ia memecahkan permasalahan kerajaan. ${ }^{40}$ Dalam konteks apa pun, Walisongo tetap membangun komitmen mempertemukan nilai-nilai Islam dengan nilai-nilai budaya lokal masyarakat Jawa. ${ }^{41}$

Keberhasilan Walisongo dalam mengembangkan agama Islam di Jawa, sebagaimana disampaikan KH. MA. Sahal Mahfudz, berupa sikap arif para wali yang bersedia mengawinkan antara budaya agama Budha ataupun Hindu yang telah ada sebelum kedatangan Islam, sebagian dibiarkan tetap hidup asal tidak

\footnotetext{
${ }^{37}$ Abdurrahman Wahid, "Paradigma Pengemban gan Masyarakat Melalui Pesantren," dalam Hairus Salim HS, ed., Menggerakkan Tradisi (Yogyakarta: LKiS, 2001), 153.

${ }^{38} \mathrm{Mart}$ in Van Bruinessen, "Global and local in Indonesian Islam" yang dimuat dalam Southeast Asian Studies (Kyoto) vol. 37, no.2 (1999), 46-63. [5]: 69).

${ }^{39}$ QS. al-Hujurāt (49): 13; QS. Ali 'Imrān (3): 159; QS al-Baqarah [2]: 62; QS. al-Mă'idah

${ }^{40}$ Ubaidillah Achmad, "Pen gantar Redaksi", dalam Abdurrahman Mas'ud, Dari Haramain Ke Nusantara: Jejak Intelekt ual Arsitek Pesantren (Jakarta: Kencana, 2006), xxviii - xxx.

${ }^{41}$ Faisal Ismail, Paradigma Kebudayaan Islam: Studi Kritis dan Analisis Historis (Jakarta: Depag RI, 2004), 55.
} 
bertentangan dengan akidah dan syariat Islam. Tidak keseluruhan praktek budaya yang telah ada sejak zaman Hindu dan Budha dihapus oleh Walisongo. Misalnya, upacara selamatan bagi orang meninggal pada tiga harinya,. tujuh harinya, empat puluh harinya, seratus harinya, pendaan, dan sewonan. Praktekpraktek seperti ini dalam Islam tidak ada, nam un demikian para wali mentolerir kebudayaan yang ada, karena dipandang tidak membahayakan akidah dan syariat orang yang melakukan kebiasaan seperti itu. Meskipun demikian, para wali tetap mengintegrasikannya dengan nilai-nilai keislaman., ${ }^{, 42}$

Pola adaptabilitas yang menyeluruh berupa pribumisasi keberagamaan Walisongo seperti disebutkan tersebut di atas adalah tidak dalam konteks merubah ajaran Islam dalam format ajaran kejawen. Keberagamaan yang dilakukan oleh Walisongo ini lebih menitikberatkan pada pola-pola transmisi dengan adat istiadat setempat (local). Namun demikian, menurut Ulil Abshar Abdalla, mereka yang tidak memahaminya akan beranggapan adaptabilitas yang menyeluruh yang digunakan Walisongo ini merupakan bentuk dari pada sinkretisme. ${ }^{43}$ Kelompok yang tidak memahami transformasi Walisongo ini merupakan kelompok sektarianisme yang selalu muncul dalam sejarah agamaagama. Kelompok sektarianis ini yang justru dalam sejarah agama menjadi ancaman serius bagi keharmonisan masyarakat (Indonesia) yang majemuk ${ }^{44}$ dan pluralis.

Sebenarnya, pola keberagamaan Walisongo ini memiliki benang merah dengan apa yang sudah dijelaskan Madjid dalam kajian al-Turast, bahwa adanya kemungkinan akulturasi timbal balik antara Islam dan budaya lokal diakui dalam suatu kaidah atau ketentuan dasar dalam ilmu Ușül al-Fiqh, yang disebut al-'àdah muhakkamah atau lebih lengkapnya al-'ádah sharí'ah muhakkamah. Secara bebas dapat difahami, bahwa adat dan kebiasaan suatu masyarakat (budaya lokal), adalah dapat dijadikan sebagai sumber hukum dalam Islam. Tapi, pada saat yang sama, harus melestarikan apa saja yang baik dan benar dari masa lampau itu dan bisa dipertahankan dalam ujian ajaran universal Islam. Contohnya adalah sikap Sunan Kalijogo tentang keruntuhan feodalisme Majapahit yang cepat dan digantikan oleh egalitarianisme Islam yang berkembang di pantai utara Jawa yang pada masanya pernah menjadi pusat-pusat perdagangan Nusantara dan internasional. ${ }^{45}$

\footnotetext{
${ }^{42}$ M. A. Sahal Mah fudz, "Islam dan Perubahan Sosial," dalam Laporan Seminar I: Pendidikan Pasca Pesantren, di Kajen Pat i, tan ggal 15 - 20 Oktober 1990 (Jakarta: P3M, 1990), 8.

${ }^{43}$ UlilAbsharAbdalla, "Serat Centini, Sinkretisme Islam, dan Dunia Orang Jawa", dalam KOMPAS, Jum'at 4 Agust us 2000, 27.

${ }^{44}$ Gre g Barton, Gagasan Liberal di Indonesia: Pemikiran Neo modemisme Nurcholis Madjid, Djohan Efendi, Ahmad Wahib, dan Abdurrahman Wahib (Jakarta: Paramadina, 1999), 330.

${ }^{45}$ Nurcholis Madjid, Islam, Doktrin dan Peradaban (Jakarta: Paramadina, 1992), 550-551.
} 


\section{Masyarakat Pasca Transformasi $W$ alisongo}

Dalam tulisan yang diambil dari hasil penelitian penulis sendiri ini, telah menemukan dua struktur masyarakat hasil transformasi Walisongo: pertama, sebuah transformasi yang ditandai dengan keberadaan pesantren. Istilah pesantren dalam pembahasan ini adalah sebuah lembaga pendidikan dan pengembangan agama Islam yang didirikan oleh Syekh Maulana Malik Ibrahim atau Syekh Maulana Maghribi di tanah air (khususnya di Jawa). Ini karena Syekh Maulana Malik Ibrahim-yang wafat pada 12 Rabi'ul Awal $822 \mathrm{H}$ bertepatan dengan 8 April 1419 M dan dikenal juga sebagai Sunan Gresikadalah orang yang pertama dari sembilan Wali yang terkenal dalam melakukan transformasi di Jawa. ${ }^{46}$ Kedua, tanda adanya sistem kasta dalam tradisi Jawa yang berkembang kuat, namun setelah muncul transformasi Walisongo menjadi masyarakat yang seimbang (egaliter).

Masyarakat pasca keberagamaan Walisongo lebih mengenal nilai keutamaan akhlāq al-karīmah. Secara etimologis, kata akhlāq menunjukkan sejumlah sifat tabiat fitri (asli) pada manusia dan sejumlah sifat yang diusahakan. ${ }^{47}$ Sifat tabiat fitri ini bisa diusahakan, berupa fitrah ilahiyyah dan insāniyyah ${ }^{48}$ dan sejum lah nilai perilaku sosial yang mempertalikan pencapaian tujuan dengan kemuliaan cara yang digunakan. ${ }^{49}$ Sejumlah sifat tabiat fitri ini merupakan dasar kebenaran et is yang sudah berkembang di tengah masyarakat zaman Walisongo, yang secara umum dapat dikatagorikan telah melampaui kepentingan salah satu agama saja, seperti jangan membunuh, jangan berdusta, jangan berzina, jangan mencuri. ${ }^{50}$ Sejumlah sifat tabiat fitri ini dapat difungsikan sepenuhnya dalam tata kehidupan masyarakat bangsa, terlepas dari bentuk negara yang digunakan. ${ }^{51}$

Berkembangnya nilai keutamaan di tengah masyarakat pasca transformasi Walisongo sebenarnya memiliki dasar dengan at uran et is yang bersumber dari istilah alwașayā al- 'asharah yang dapat dibaca dalam QS al-An'ām [6]: 151152. Ayat-ayat ini menjelaskan sepuluh wasiat Tuhan (alwasăàā al'asharah)

\footnotetext{
${ }^{46}$ Wahjoetomo, Perguruan Tinggi Pesantren: Pendidikan Alternatif Masa Depan (Jakarta: Gema Insan i Press, 1997), 70-71.

${ }^{47}$ Ali Abdul Halim Mahmud, Karakteristik Umat Terbaik: Telaah Manhaj, Aqidah dan Harakah (Jakarta: Gema In san i Pres, 1996), 95-96.

${ }^{48}$ Ubaidillah Achmad, "Fitrah dan Potensi Insani dalam Ilmu tasawuf", dalam Jurnal Konseling Relegi, ST AIN Kudus, Vol. 1, Nomor 1 (2010), 1-38.

${ }^{49}$ Abdurrahman Wahid, "Islam dan Masyarakat Bangsa," 75.

${ }^{50} \mathrm{~K}$. Bertens, Et ika (Jakarta: Gramedia, 1999), 36.

${ }^{51}$ Nurcholis Madjid, Islam, Doktrin dan Peradaban (Jakarta: Paramadina, 1992), 384.
} 
yang ditunjukkan kepada manusia. ${ }^{52}$ Wasiat-wasiat ini merupakan prinsip hukum yang harus dipedomani dalam hidup bermasyarakat. Peraturan etika universal ini bisa berupa: larangan mempersekutukan sesuatu dengan Allah, perintah berbuat baik terhadap kedua orang tua ibu-bapak, larangan membunuh anak-anak mereka karena takut kemiskinan, larangan mendekati perbuatan yang keji (baik dengan terang-terangan maupun dengan sembunyi), larangan menghilangkan nyawa orang yang diharamkan Allah (kecuali dengan alasan yang sah), larangan mempergunakan harta anak yatim (kecuali dengan cara yang lebih bermanfaat), perintah untuk menyempurnakan takaran dan timbangan dengan adil, jangan membebani orang lain yang tidak menyanggupinya, perintah untuk bertutur kata secara adil meskipun orang yang diajak berbicara itu adalah kerabatnya sendiri, dan perintah untuk memenuhi janji Allah.

Meskipun Walisongo menawarkan sebuah nilai keutamaan keberagamaan yang diyakininya berupa alwașayā al'asharah ini, namun transformasi Walisongo tetap mempertimbangkan tradisi lokal. Hal ini merupakan sebuah keniscayaan yang tidak dapat dielakkan Charles Horton Cooley, yang dikupas oleh K.J. Veeger dalam buku Realitas Sosial. Cooley menyebutkan bahwa masyarakat dan individu itu bukan dua realitas yang berdiri terpisah, melain kan dua sisi atau segi dari realitas yang satu dan sama. Masyarakat dan individu dapat diumpamakan sebagai bentuk dua sisi keping uang yang tidak mungkin terpisahkan. Karenanya, setiap kehidupan itu dapat dipandang dari segi individualitasnya dan sosialitasnya. ${ }^{53}$ Pandangan ini diperkuat David Kaplan dan Albert A. Manners, bahwa manusia melakukan adaptasi terutama lewat mekanisme budayanya, dan oleh sebab itu cara adaptasinya unik. ${ }^{54}$ Karena itu, adanya kecenderungan formalisasi ajaran Islam dalam masyarakat atau islamisasi dalam bentuk manifestasi simbolik hanya akan menimbulkan kekeringan dalam pelaksanaan keberagamaan.

Hubungan kultural antara raja dan rakyat atau sebaliknya relasinya dengan peran kehambaan di hadapan Allah $\mathrm{Swt}^{55}$ merupakan bukti keberhasilan Walisongo memperkenalkan prinsip etika universal di tengah masyarakat. Namun demikian, Walisongo tetap melakukan kerja transformatif secara berkelanjutan. Transformasi secara berkelanjutan it u dengan selalu menekankan

\footnotetext{
${ }^{52}$ Dalam tradisi Yahudi-Kristen aturan et is in i dikumpulkan dalam "dekalog" atau sepuluh perintah Allah (the ten commandments). K. Bertens, Etika, 36.

${ }^{53}$ K.J. Veeger, Realitas Sosial: Refleksi Filsafat Sosial atas Hubungan Individu-Masyarakat dalam Cakrawala Sejarah Sosiologi(Jakarta: Gramedia, 1993), 107.

${ }^{54}$ David Kaplan dan Albert A. Manners, Teori Budaya, terj. Landung Simatupang (Yogyakarta: Pustaka Pelajar, 1999), 116.

${ }^{55}$ Abdurrahman Mas'ud, Dari Haramain Ke Nusantara: Jejak Intelektal Arsitek Pesantren (Jakarta: Kencana, 2006), 52.
} 
kualitas pembentukan karakter kepribadian Muslim, baik secara vertikal (hablun min Allāh) maupun horizontal (hablun min al-nās). Dalam kerja transformatif ini, walisongo dan para penguasa kerajaan Jawa sangat mempertimbangkan undang-undang dan kebutuhan yang didasarkan pada akarakar budaya masa lampau. ${ }^{56}$ Transformasi keberagamaan Walisongo ini didasarkan pada nilai ajaran agama Islam yang memiliki spektrum moral yang luas.

Keberhasilan Walisongo dalam melakukan transformasi secara berkelanjutan ini telah dimulai dari kerpibadiannya yang sangat kharismatik yang didasarkan pada nilai-nilai profetik (șidq, amānah, tabliqhh, dan fatānah). Sebagai seorang wali selain memiliki kekuatan ajaran keutamaan yang diperkenalkan kepada masyarakat, mereka ini juga memiliki karakter kepribadian yang sangat $m$ atang dan stabil. Karakter kepribadian ini terlihat dari kemampuan mengelola kecerdasan: intelektual, emosional, spiritual dan attitude. Istilah kharisma dalam kepribadian Walisongo ini memiliki kesamaan arti dengan kata al-haibah, yang sering digunakan untuk menyebut kewibawaan yang dimiliki oleh para kyai khass.

Kepribadian karismatik ini dicirikan dengan dua prasyarat utama: pertama, memiliki sifat ideal yang dijunjung tinggi oleh masyarakat reseptif. Jika seseorang tidak memiliki nilai ideal yang dijunjung masyarakat, maka tidak akan menyandang predikat tokoh kharismatik. Kedua, kemampuan kharismatik itu didasarkan pada kemampuan keilmuan dan ketakwaan subjek/individu yang tinggi sebagai cerminan sifat kehambaan penuh dihadapan Sang al-Maula. Di dalam konteks sifat kharismatik yang terpancar dalam kepribadian Walisongo, ditegaskan Hiroko Horikoshi, sebagai potensi kekuatan Walisongo yang berhasil menimbulkan rasa kagum orang-orang di sekitarnya. ${ }^{57}$

Kedatangan Walisongo tidak pernah mempersoalkan simbol kekuasaan. Isu keberagamaan yang muncul pada zamannya lebih menekankan pada pentingnya membangun persamaan, keadilan, dan kemanusiaan. Ketiga penekanan ini mewarnai pola integrasi nilai ajaran Islam dan kultur lokal di satu sisi, sedangkan di sisi yang lain mempengaruhi proses dinamisasi keberagamaan Walisongo yang didasarkan pada nilai universal agama-agama besar. Kekuatan kepribadian Walisongo ini, yang sangat pantas dijadikan sebagai tokoh yang bisa dijadikan modeling kepribadian dan keberagamaan di tengah budaya lokal masyarakat. Istilah dinamisasi dalam tulisan ini, pernah dimunculkan Wahid, sebagai landasan budaya (cultural basic) yang sangat

\footnotetext{
${ }^{56}$ Abdurrahman Wahid, "Pengembangan Fiqh yang Kontekstual", dalam Pesantren, No. 2, Vol.II (1985), 8.

${ }^{57}$ Hiroko Horikoshi, Kyai dan Perubahan Sosial, terj. Umar Basalim (Jakarta: P3M, 1987), 226.
} 
diperlukan dalam transformasi keberagamaan. Dinamisasi dalam tulisan Wahid, memiliki relasi makna dengan upaya penggalakan kembali nilai hidup positif yang telah ada dan pergantian nilai lama itu dengan nilai baru yang dianggap lebih sempurna.

Karenanya, istilah modernisasi sebenarnya terkandung proses dinamisasi. Sedangkan, istilah dinamisasi ${ }^{58}$ memiliki konotasi proses perubahan keadaan yang disesuaikan dengan sikap hidup dan peralatan yang telah ada sebagai dasar. Sikap hidup ini sangat terkait dengan keyakinan, konsep -konsep yang dirasa asing ketika dihadapkan tantangan dan hambatan. Karenanya, dengan dinamisasi keberagamaan telah memudahkan transformasi Walisongo di tengah masyarakat. Secara sosiologis, dengan tanpa dasar kesadaran pentingnya dinamisasi keberagamaan, maka akan sulit dilakukan upaya pribumisasi agama. Dinamisasi ini, akan menghindarkan subjek dari sikap eksklusif, yaitu sikap yang merusak tata nilai hubungan antar manusia (mubasharah), ${ }^{59}$ seperti antara kaum rakyat dan kaum raja, kaum miskin dan kaum kaya, kaum ploretar dan kaum borjuis, masyarakat desa dan kota, mereka yang terdidik dan mereka yang tidak terdidik, kesenjangan material dan intelektual, keberagamaan kesukuan tertentu. ${ }^{60}$

\section{Demokratisasi Keberagamaan Individu}

Penyebab runtuhnya bangunan keragaman dan bangunan nilai keutamaan itu lebih banyak diakibatkan oleh pola keberagamaan individu yang sangat eksklusif. Karenanya, kehidupan tradisional yang feodalistik-paternalistik dan cenderung ke arah totalitarianisme harus segera dijauhkan dari lingkungan individu. Dengan demikian, karakter individu bisa diisi dengan dua sikap tanggung jawab: pertama, agar setiap individu berpegang pada prinsip keterbukaan dan keragaman budaya keberagamaan. Kedua, setiap individu harus tetap teguh melaksanaan keberagamaan yang didasarkan pada nilai keutamaan prinsip etika universal Walisongo.

Prinsip etika universal sejarah keberagamaan Walisongo dapat dipahami dari beberapa nilai keutamaan: sikap dan berkata secara jujur, berbuat baik kepada kedua orang tua, menjaga keselamatan jiwa, menjauhi perbuatan keji (homoseks, seks bebas, dan inses), menjaga harta anak yatim sampai dewasa, menyempurnakan takaran dan timbangan dengan adil, meringankan beban pihak lain yang di luar kesanggupannya, menegakkan kebenaran (QS. al-An'äm

\footnotetext{
${ }^{58}$ Abdurrahman Wahid, "Dinamisasi dan Modernisasi Pesantren," dalam Hairus Salim HS, ed., Menggerakkan Tradisi (Yogyakarta: LKiS, 2001 ), 38.

${ }^{59}$ HR. Bukhori: $1228,1229,1268,1750,2235,3162,3697$; HR. Muslim: 1593.

${ }^{60}$ Hassan Hanafi, "Asal-Usul Konservatisme Keagamaan dan Fundamentalisme Islam" Ulumul Qur'an, No. 7, Vol. 3 (1990), 18-25.
} 
[6]:150-153), melaksanakan kebebasan beragama (QS. al-Baqarah [2]: 256), menegakkan prinsip persamaan, prinsip tolong menolong dalam kebaikan (QS. al-Mä'idah [5]: 2), dan prinsip toleransi (QS. al-Käfirūn [109]: 1-6).

Pentingnya pembentukan karakter individu tersebut di atas, penting pula disosialisasikan sebuah nilai keutamaan, yakni kesadaran hidup bersama dan mewujudkan suatu masyarakat yang bersat u yang terlepas dari kecurigaan serta prasangka negat if di tengah pluralitas budaya. Keberadaan masyarakat madani yang dicita-citakan hanya merupakan suatu utopia tanpa dilengkapi dengan kemampuan-kemampuan individual dalam mengendali diri (soft skill) di tengah civil society. Karenanya, keberlangsungan demokratisasi keberagamaan individu meniscayakan kesiapan potensi fitrah individu, baik ilahiah dan insaniah di tengah keragaman budaya.

Pembetukan karakter individu sebagai target transformasi agama dalam teks Walisongo, bisa secara kontekstual dibangun di tengah sistem negara bangsa (nation state). Demikian ini didasarkan pada wilayah transformasi agama Walisongo yang merupakan suatu transformasi yang berbentuk bukan at as dasar etnisitas, kultur, dan bahasa atau kedudukan geografis-melainkan keimanan. Karena keimanan itu melampaui semua bentuk perkembangan sejarah pemikiran umat manusia, maka transformasi agama yang dikembangkan Walisongo pada sistem kerajaan-feodalistik-paternalistik dapat diterapkan pada konteks negara-bangsa, sekularisasi, pluralisasi, liberalisasi, baik liberalisasi ekonomi maupun liberalisasi pemikiran keagamaan. Demikian ini juga sesuai dengan nilai keutamaan ajaran agama Islam, yaitu sebagai agama perdamaian (dīn al-saläm), sebagai agama perbaikan (dīn al-iṣlăh) dan agama kasih sayang (din al-mahabbah wa al-mawaddah).

Transformasi agama tidak hanya berfungsi mengendalikan individu dalam sistem kerajaan dan kultur feodalistik-paternalistik, tetapi lebih luas lagi untuk membangun karakter kepribadian individu supaya mendapatkan pembebasan dan pencerahan secara eksistensialis. Karenanya, transformasi agama yang dikenalkan Walisongo tidak hanya dibatasi sebuah perkampungan yang bernama "bangsa",yaitusebuah komunitas umat yang besar yang berkumpul di dalamnya suku-suku (al-ummah al-kabírah tajma'u qaba',il). Dalam pandangan Wahid, pengertian Al-Qur'an mengenai "bangsa", terbatas hanya sebagai satuan etnis yang mendiami teritorial yang sama. Sedangkan wawasan kebangsaan di masa modern ini sudah berarti lain, yaitu satuan politis yang didukung oleh sebuah ideologi nasional atau ideologi negara bangsa (nation state).

Oleh karena itu, membaca demokratisasi keberagamaan Walisongo haruslah dilihat dari perspektif bangunan nilai keutamaan yang diusung untuk membentuk karakter individu. Bangunan nilai keutamaan pun bisa dengan jalan 
dan cara yang berbeda, seperti: memahami, memaknai dan menerapkan teks Walisongo yang didasarkan pada nilai keutamaan prinsip etika universal. Sebagai perbandingan, maraknya konflik budaya dan konflik inter-antar agama yang berkembang sekarang ini merupakan bentuk tercerabutnya akar keutamaan prinsip etika universal yang pernah dibangun Walisongo di tengah keragaman budaya dan keberagamaan individu. Jika sekarang sering ditemukan konflik berupa aksi kekerasan yang mengatasnamakan agama, maka yang demikian ini lebih disebabkan pada sistem keberagamaan yang salah.

Dalam komunikasi keberagamaan sebagaimana yang telah dicontohkan Walisongo, supaya lebih mengedepankan sikap penuh hikmah dan tutur sapa yang bersahaja dan egaliter (bi al-p̣ikmah wa al-mau'zah al-ḥasanah). Ini artinya, dalam komunikasi keberagamaan yang dilakukan inter-antar umat beragama tidak perlu mengedepankan konfrontatif dan reaktif. Justru yang lebih penting pola komunikasi harus lebih diarahkan pada: upaya mempengaruhi individu dan masyarakat untuk lebih memperhatikan golongan lemah (al-mustad'afïn), golongan miskin (al-masäkinn) golongan tak berdaya atau yang termarginalkan (al-fuqārá). Upaya yang demikian ini dapat dilestarikan di sekolah, pesantren, seminari-seminari, dan tempat penyemaian tunas generasi muda.

Adanya gerakan formalisasi Islam akan berujung pada berdirinya negara Islam dan komunalisme gerakan Islam. Jadi, harus segera dihentikan pola formalitas keberagamaan, karena hal ini hanya akan membuat individu menjauhi keragaman dalam keberagamaan dan menutup keterbukaan serta menutup ruang demokratisasi kehidupan sosial. Selain itu, formalisasi keberagamaan bertentangan dengan konsep Islam sebagai rahmatan li al'älamīn. Dengan kata lain, mengenalkan nilai keutamaan Walisongo sama artinya dengan melakukan upaya memanusiakan manusia yang mengalami dehumanisasi karena sistem dan struktur yang tidak adil. Prinsip kultural keberagamaan yang dikenalkan Walisongo ini, dalam tulisan Sukmadinata, dapat difungsikan, pertama, untuk mencapai tujuan yang sekarang dan yang akan datang. Kedua, kepentingan dirinya dan masyarakat, baik sebagai pribadi, warga masyarakat maupun karyawan.",61

Secara filosofis, nilai keutamaan prinsip etika universal yang diusung Walisongo merupakan cara Walisongo mengembangkan paradigma berfikir et is dalam membentuk kepribadian yang positif, kepribadian yang benar-benar mampu menumbuhkan potensi qalb, aql dan nafs supaya tidak jatuh pada alnafs al-'ammārah bi al-sū', karena dengan jatuhnya diri pada politik

\footnotetext{
${ }^{61}$ Nana S Sukmadinata, Landasan Psikologi Proses Pendidikan (Bandung: Remaja Rosdakarya, 2005), 10.
} 
kepentingan pribadi (al-nafs al-'ammärah bi al-sū'), justru akan menjerumuskan pada kehancuran individu di tengah relasi kehidupan umat manusia. Dengan upaya ke arah pembentukan kepribadian yang seperti ini merupakan satu cara Walisongo mengajarkan keragaman (teaching diversity). ${ }^{62}$ Target dari pengajaran keragaman adalah rasionalisasi etis, ideal-ideal inklusifisme, pluralisme, imperatif humanistik. Target yang demikian inilah yang menjadi prasyarat terjadinya partisipasi sipil dalam demokrasi multikultural.

\section{Penutup}

Demokratisasi keberagamaan individu yang dibangun Walisongo merupakan contoh keberhasilannya bidang pengembangan multikulturalisme. Dalam kawasan studi ilmu sosial, keberhasilan Walisongo merupakan bentuk keberhasilan dalam kawasan rekonstruksi sosial. Program rekonstruksi sosial ini yang dalam sosiologi lebih diarahkan pada tujuan untuk menyatukan perbedaan kultural dan menentang ketimpangan yang ada dalam masyarakat. Program critical multicultural education ${ }^{63}$ ini dilakukan para wali dalam setiap mengkritisi perkembangan budaya masyarakat. Contoh kasus pada pembahasan penerapan hak asasi manusia, ${ }^{64}$ konteks HAM ini yang merupakan salah satu pendorong pelaksanaan transformasi agama yang sedang mengalami kelesuan dan kekeringan serta mengusik ketentraman sesama umat manusia.

Kegigihan Walisongo membangun pentingnya sebuah kesadaran universal kemanusiaan, persamaan dan keadilan merupakan bentuk keberadaannya yang sangat humanis yang hingga sekarang telah dilanjut kan dalam tradisi pesantren. Dalam tulisan Abdurrahman Wahid, dijelaskan akar-akar keilmuan yang dipelajari di pesantren memiliki bukti-bukti akar keilmuan yang humanis. ${ }^{65}$ Namun demikian, justru humanitas Walisongo yang ditemukan dalam tradisi pesantren telah terkubur dengan menghalalkan segala cara dan mengedepankan eksklusivitas keberagamaan. Sikap eksklusif ini, dalam perumpamaan Wahid, tidak melihat agama secara fungsional namun hanya sebatas ornamental belaka dari pelaksanaan agama langit (samawi) itu. ${ }^{66}$ Yang perlu diingat, agama memiliki pengaruh terhadap perkembangan HAM dan pejuang demokrasi di

\footnotetext{
${ }^{62}$ HAR. Tilaar, Multikulturalisme: Tantangan-tantangan Global Masa Depan dalam Transformasi Pendidikan Nasional (Jakarta: Grasindo, 2004), 99-100.

${ }^{63}$ Pepi Leistyna, Defining \& Designing Multiculturalism (Albany: State University of New York Press, 2002), 933.

${ }^{64} \mathrm{~A}$ Ghaffar Karim, Metamorfosis NU dan Politisasi Islam Indonesia (Yogyakarta: LKiS, 1995), 104.

${ }^{65}$ Abdurrahman Wahid, "Asal usul Tradisi Keilmuan di Pesantren", dalam Hairus Salim HS, ed., Menggerakkan Tradisi(Yogyakarta: LKiS, 2001), 157.

${ }^{60}$ Abdurrahman Wah id, "Hindari Negara Berasumsi A gama," dalam Media Indonesia, Jum'at 13 November 1998,6 .
} 
negeri ini, ${ }^{67}$ namun bukan berarti kepentingan personal atau komunal yang mengatasnamakan agam a dibiarkan melaju kencang.

\section{Daftar Pustaka}

al-Qur'ān al-Karìm

Achmad, Ubaidillah. "Epilog: Agama di Balik Fakta Politik", dalam Negara Islam Menurut Konsep Ibn Khaldun. Yogyakarta: Gama Media, 2007. . "Pengantar Redaksi," dalam Abdurrahman Mas'ud, Dari Haramain Ke Nusantara: Jejak Intelektual Arsitek Pesantren. Jakarta: Kencana, 2006.

__ . "Fitrah dan Potensi Insani dalam Ilmu tasawuf," dalam, Jurnal Konseling Religi, ST AIN Kudus, Vol. 1, No. 1 (Januari-Juni 2010).

__ . "Pendidikan Multikultural Gagasan Walisongo Menuju Keutamaan Individu dan Budaya Lokal", Jurnal Pendidikan Islam (Jakarta), Vol. IX No. 2 (Juli-Desember 2006).

Abshor-Abdalla, Ulil. "Humanisme Kitab Kuning: Refleksi dan Kritik atas Tradisi Intelektual Pesantren," Jurnal Pesantren, Vol. IX, No. I (1992): 75-82.

—_ "Serat Centini, Sinkretisme Islam dan Dunia Orang Jawa." KOMPAS, 4 Agustus 2000.

___ "Emoh Negara: Menuju Paradigma "Gerakan Sosial." KOMPAS, 2324,2000 .

—_ . "Beberapa Kendala Prakt is Dialog Antaragama." KOMPAS, 5 Agust us 2000.

Alsa, Asmadi. Pendekatan Kuantitatif dan Kualitatif serta Kombinasinya dalam Penelitian Psikologi. Yogyakarta: Pustaka Pelajar, 2003.

Abdullah, M., Amin. Studi Agama: Normativitas atau Historisitas?, Yogyakarta: Pustaka Pelajar, 1999.

—_. Dinamika Islam Kultural. Bandung: Mizan, 2000.

A'la, Abdullah. "Kemenangan Gus Dur Angin Sejuk bagi Iklim Keagamaan di Indonesia." KOMPAS, 22 Oktober 1999.

Asfar, Muhammad. "Ulama' dan Politik dalam Perspekt if Masa Depan," Jurnal Ulumul Qur'an, Vol. VI, No. 5 (1996): 4-14.

Am in, M., Masyhur, ed. NU dan Ijt ihad Politik Kenegaraannya. Yogyakarta: alAmin, 1996.

Agama, Demokrasi dan Transformasi Sosial. Yogyakarta: LKPSM, 1985

\footnotetext{
${ }^{67}$ Abdurrahman Wahid, "Demokrasi di Negeri Ini Timbul dari Agama, dalam KOMPAS, 30 Desember 2001,2 .
} 
Abdullah, Masykuri. "Islam and The Concept of Nation State", Makalah Seminar IAIN Walisongo Semarang, 5-8 November 1999.

"Gagasan dan Tradisi Bernegara dalam Islam: Sebuah Perspekt if Sejarah dan Demokrasi Modern", Jurnal Tashwirul Afkar, No. 7 (2000).

Al-Jaziri, Abu Bakar Jabir. Pola Hidup Muslim. Diterjemahkan oleh Rahmat Jatmiko. Bandung: Rosdakarya, 1993.

Al-Jabiri, Muhammad Abid. Post Tradisionalisme Islam. Diterjemahkan oleh Ahmad Baso. Yogyakarta: LKiS, 2000.

Ali, Muhammad. "Paradigma Baru Misi Agama-Agama." KOMPAS, 14 Juli 2000,4 .

Amir Aziz, Ahmad. Neo-Modernisme Islam di Indonesia: Gagasan Sentral Nurcholish Madjid dan Abdurrahman Wahid. Jakarta: Rineka Cipta, 1999.

Afendi, Arif. Islam Demokrasi Atas Bawah. Yogyakarta: Pustaka Pelajar, 1997.

A Steenbrink, Karel. Pesantren Madrasah Sekolah: Pendidikan Islam dalam Kurun Modern. Jakarta: LP3ES, 1974.

Ali, Fachri. "Keharusan Demokratisasi Islam di Indonesia," Jurnal Ulumul Qur'an, Vol. VII, No. 1 (1995): 8-19.

Arifin, Syamsul. "Menakar Otentisitas Islam Liberal," Jawa Pos, Jum'at, 1 Februari 2002.

Anam, Choirul. Pertumbuhan dan Perkembangan NU. Surabaya: Bisma Satu, 1999.

Azra, Azyumardi. Pergolakan Politik Islam: Dari Fundamentalisme, Modernisme Hingga Post-Modernisme. Jakarta: Paramadina, 1996.

- "Islam dan Negara: Eksperimen dalam Masa Modern (Tinjauan SosioHist oris)", Jurnal Ulumul Qur'an, No. 2, Vol. IV (1993): 10-16.

Barton, Greg, ed. Nahdlatul Ulama, Traditional Islam and Modernity in Indonesia. Australia: Monash Asia Institute, 1996.

—_ Gagasan Islam Liberal di Indonesia: Pemikiran Neo-Modernisme Nurcholish Madjid, Djohan Effendi, Ahmad Wahib, dan Abdurrahman Wahid. Jakarta: Param adina, 1999.

Brebesi, Ma'mun Murod Al. Menyingkap Pemikiran Abdurrahman Wahid dan Amien Rais tentang Negara. Jakarta: Raja Grafindo Persada, 1999.

Baso, Ahmad. Civil Society Versus Masyarakat Madani. Bandung: Pustaka Hidayah, 1999.

Bagus, Lorens. Kamus Filsafat. Jakarta: Gramedia, 2000.

Baehaqi, Imam, ed. Kontroversi Aswaja. Yogyakarta: LKiS, 1999.

Bertens, K. Etika, Jakarta: Gramedia, 1999.

Braaten, Carl. History and Hermeneutics. Philadelpia: Fortress, 1966.

—__. "Menyambung Refleksi tentang Pendasaran Hak Asasi Manusia." KOMPAS, 1 Desember $2001, .31$. 
Ubaidillah Achmad (89-123)

Bruinessen, Martin van. NU, Tradisi, Relasi-Relasi Kuasa dan Pencarian Wacana Baru. Yogyakarta: Pustaka Pelajar, 1993.

Dharwis, Ellyasa KH, ed. Gus Dur, NU dan Masyarakat Sipil. Yogyakarta: LKiS, 1994.

Dhofier, Zamakhsyari. Tradisi Pesantren: Studi tentang Pandangan Hidup Kiai. Jakarta: LP3ES, 1985.

Effendi, Bahtiar. Islam dan Negara: Transformasi Pemikiran dan Praktek Politik Islam di Indonesia. Diterjemahkan oleh Ihsan Fauzi. Jakarta: Paramadina, 1998.

Palmer, Richard E. Hermeneutics; Interpretation Theory in Schleiermacher, Dilthey, Heidegger, and Gadamer. Evanston: Northwestern University Press, 1969.

Falakh, Muhammad Fajrul et al. Membangun Budaya Kerakyatan: Kepemimpinan Gus Dur dan Gerakan Sosial NU. Yogyakarta: Titian Ilahi Press, 1997.

Freire, Paulo et al. Menggugat Pendidikan. Yogyakarta: Pustaka Pelajar, 1999.

Falk, Richard. "Universalitas yang Keliru Geopolitik Penyingkiran terhadap Islam," Jurnal Ulumul Qur'an, Vol. VII, No. 6 (1997).

Gie, The Liang. Ilmu Politik. Yogyakarta: Yayasan Studi Ilmu dan Teknologi, 1990.

Gellner, Ernest. Menolak Posmodernisme: Antara Fundamentalisme Rasionalis dan Fundamentalisme Relegious. Diterjemahkan oleh Hendro Prasetyo. Bandung: Mizan, 1994.

—_ Muslim Society. US A: Cambridge University Press, 1999

Geertz, Clifford. The Religion of Java. USA: The University of Chicago Press, 1960.

Gaffar, Affan. Politik Indonesia: Transisi Menuju Demokrasi. Yogyakarta: Pustaka Pelajar, 1999.

Giddins, Anthony. Capitalism \& Modern Social Theory. Australia: Cambridge University Press, 2000.

Hanafi, Hasan. Al-Turäth wa al-Tajdìd: Min al-'Aqìdah Ila al-Thaurah. Libanon: Dar al-Fikr, 1988.

___ "Asal-usul Konservatisme Modern dan Fundamentalisme", Jurnal Ulumul Qur'an, Vol. II, No. 7 (1989): 18-25.

—__ Agama, Ideologi, dan Pembangunan. Diterjemahkan oleh Shonhaji Shaleh. Jakarta: P3M, 1991.

Hamim, Thoha. "Islam dan Civil Society: Tinjauan tentang Prinsip Human Rights, Pluralism dan Religious Tolerance." Surabaya: Makalah Seminar Pusat Informasi dan Kajian Islam IAIN Sunan Ampel, 1999. 
Haurani, Albert. Arabic Thought in the Liberal Age (1798-1939). USA: Cambridge University Press, 1995.

Harjanto, N. T. Budi. "Studi Pembangunan Politik: Dari Modernisasike Demokrat isasi", Analisis CSIS, Th. XXVII, No. 2 (April-Juni 1998).

Hamzah, Imron dan Anam, Choirul. Gus Dur Diadili Kiai-Kiai. Surabaya: Bisma Satu, 1998.

Hiroko, Horikoshi. Kyai dan Perubahan Sosial. Diterjemahkan oleh Umar Basalim. Jakarta: P3M, 1987.

Howard, Roy J. Hermeneutika: Pengantar Teori-Teori Pemahaman Kontemporer. Jakarta: The Ford Foundation, 1999.

Husain, Syaukat. Hak Asasi Manusia dalam Islam. Jakarta: Gema Insani Press, 1996.

Haddad, Yaounne Yazbeck. Contemporary Islam and the Challenge of History. New York: State University of New York Press, 1982.

Hendrik, Meuleman, Johan. Tradisi, Kemodernan dan Metamodernisme. Memperbincangkan Pemikiran Muhammad Arkoun. Yogyakarta: LKiS, 1996.

Hikam, A.S., Muhammad. Demokrasi dan Civil Society. Jakarta: LP3ES, 1999. Politik Kewarganegaraan, Jakarta: Erlangga, 1999.

Hegel, G.W.F. Filsafat Sejarah. Diterjemahkan oleh Cuk Ananta Wijaya. Yogyakarta: Pustaka Pelajar, 2001.

Hidayat, Komaruddin. "Devaluasi Simbol Agama yang Bangkitkan Emosi Masa." KOMPAS, 15 November 2001, 3. ed. Passing Over: Melintas Batas Agama. Jakarta: Paramadina, 1999 . "Ambivalensi Agama dan Demokrasi: Apresiasi dan Catatan untuk Presiden Abdurrahman Wahid." KOMPAS, 19 Januari 2002, PP. 4. Haryatmoko. "Etika Politik dan Civil Society." KOMPAS, 5 Juni 2001.

—_. "Mencari Akar Fanatisme Ideologi, Agama, atau Pemikiran." KOMPAS, 20 Desember 2001, 3.

—_ . "Budaya Politik Santun dan Pluralisme." KOMPAS, 2 Februari 2002, 28.

Harahap, Syahrin. Al-Qur'an danSekularisasi. Yogyakarta: Tiara Wacana, 1994 Harsojo. Pengantar Antropologi. Bandung: Putera A. Bardin, 1999.

Hasan, Jauhar Hatta, ed. Islam Kebangsaan: Fiqh Demokratik Kaum Santri. Jakarta: Pustaka Ciganjur, 1999.

Haque, Ziaul. Wahyu dan Revolusi. Diterjemahkan oleh E Setiawati alKhattab. Yogyakarta: LKiS, 2000.

Harvey, Van A. "Hermeneutic", dalam Marcea Eliade, The Encyclopedia of Religions, New York: Mac Milan Publishing Co, Vol. 6.

Isre, Muh. Shaleh, ed. Tuhan Tidak Perlu Dibela. Yogyakarta: LKiS, 2000. 
Prisma Pemikiran Gus Dur. Yogyakarta: LKiS, 2000.

Irsyam, Mahrus. "Hukum Rimba Politik Indonesia." dalam Gatra, 18 Juli 1999.

INCReS, Tim. Jejak Antropologi Pemikiran dan Gerakan Gus Dur. Bandung: Remaja Rosda karya, 2000.

Ida, Laode. "Pergaulan dan Identitas NU”, Jurnal Ulumul Qur'an, Vol. VI, No. 5 (1995).

__ . "Problem Demokrasi dan "Civil Society' di Negara-Negara Arab", Jurnal Tashwirul Afkar, edisi No. 7 (2000): 43-58.

Kuntowijoyo. Identitas Politik Umat Islam. Bandung: Mizan, 1996.

"Radikalisasi Islam." KOMPAS, 20 Februari 2001, 4.

Khadduri, Madjid. Teologi Keadilan: Perspektif Islam. Surabaya: Risalah Gusti, 1999.

Kumar, Ranjit. Research Methodology, A Step-By-Step Guide for Beginners, London: SAGE Publications, 1999.

Kazuo, Shimogaki. Kiri Islam. Diterjemahkan oleh M. Imam Aziz dan Jadul Maula. Yogyakarta: LKiS, 1997.

Karim, A. Gaffar. Metamorfosis NU danPolitisasi Islam Indonesia. Yogyakarta:

LKiS, 1995.

Koentjaraningrat. Sejarah Teori Antropologi II. Jakarta: UI-Press, 1990.

Kaplan, David dan A. Manners Albert. Teori Budaya. Yogyakarta: Pustaka Pelajar, 1999.

Kleden, Ignas. "Moral, Agama, dan Negara." KOMPAS, 21 Juli 1999, 5. 42.

Karni, S. Asrori, Civil Society \& Ummah. Jakarta: Logos, 1999.

Lewis, Bernard. Bahasa Politik Islam. Diterjemahkan oleh Ihsan Ali Fauzi. Jakarta: Gramedia, 1995.

—_. The Arabs in History. US A: Harper Colophon Books, 1966.

L., Esposito, John. Ancaman Islam Mitos atau Realitas. Diterjemahkan oleh Alwiyah Abdurrahman dan Mssi. Bandung: Mizan, 1996.

—_. Identitas Islam pada Perubahan Sosial Politik. Diterjemahkan A. Rahman Zainuddin. Jakarta: Bulan Bintang, 1985.

Lopa, Baharuddin. Al-Qur'an \& Hak Asasi Manusia. Yogyakarta: Dana Bakti Prisma Yasa, 1997.

Musawi, A. Syarafuddin Al. Isu-Isu Penting Ikhtilaf. Bandung: Mizan, 1989.

Magnis-Suseno, Frans. "Religious Versus Sekuler Humanisme?" Semarang:

Makalah Seminar Internasional IAIN Walisongo Semarang, 2000.

Mas'ud, Abdurrahman. The Pesantren Architecs and Their Socio-Religious Teachings (1850-1950). Los Angeles: UMI, 1997. 
Mahmud, Ali Abd. Halim. Karakteristik Umat Terbaik. Jakarta: Gema Insani Press, 1996.

Marijan, Kacung. Quo Vadis NU: Setelah Kembali ke Khittah 1926. Jakarta: Erlangga, 1992.

—_ - ed. Mengurai Hubungan Agama dan Negara. Jakarta: Gramedia, 1999.

Muzani, Saiful. "Identitas Negara Bangsa dan Kebangkitan Islam: Perbandingan Malaysia dan Indonesia, Jurnal Studia Islamika, Vol. 1, No. 2 (1994): 157-185.

Madjid, Nurkholis. Memberdayakan Masyarakat, Menuju Negeri yang Adil, Terbuka dan Demokratis. Jakarta: Paramadina, 1996.

__ Islam, Doktrin, dan Peradaban. Jakarta: Param adina, 1992.

—_. Dialog Keterbukaan: Artikulasi Nilai Islam dalam Wacana Sosio Politik Kontemporer. Jakarta: Paramadina, 1997.

—_ . "Menuju Masyarakat Madani", Jurnal Ulumul Qur'an, Vol. VII, No. 2 (1996): 51-55.

Mas'oed, Mohtar. Perbandingan Sistem Politik. Yogyakarta: Gajah Mada University Press, 1994.

Maududi, Abu A'la al. Khilafah dan Kerajaan. Diterjemahkan oleh Muhammad al-Baqir. Bandung: Mizan, 1984.

Moeliono, Anton M. Kamus Besar Bahasa Indonesia. Jakarta: Balai Pustaka, 1993.

Minhaji, Akh. "Hak-Hak Asasi Manusia dalam Hukum Islam: Penafsiran Baru tentang Posisi Minorit as non-Muslim”, Jurnal Ulumul Qur'an, Vol. V, No. 2 (1993): 16-31.

Mahfudz, Sahal. "Islam dan Perubahan Sosial”. Semarang: Makalah Seminar P3M, 1990.

Noer, Deliar. Gerakan Modern Islam di Indonesia 1900-1042. Jakarta: LP3ES, 1991

—_ Pemikiran Politik di Negeri Barat. Bandung: Mizan, 1999.

Nasir al-Syu'di, Abdurrahman. Tafsir Kalam al-Manan. Riyadh: Al-Mamlakah al-Arabiyah, $1410 \mathrm{H}$.

Paige, Glenn D. Islam Tanpa Kekerasan. Diterjemahkan oleh M. Taufiq Rahman. Yogyakarta: LKiS, 1999.

P., Huntington. "Benturan antara Peradaban, Masa Depan Politik Dunia?", Jurnal Ulumul Qur'an, Vol. IV, No. 5 (1992): 11-25.

Pranowo, M. Bambang. "Islam dan Pancasila: Dinamika Politik Islam di Indonesia ", Jurnal Ulumul Qur'an, Vol. III, No. 1 (1993): 4-14.

Parera, Frans M, ed. Gus Dur Menjawab Perubahan Zaman, Jakarta: Penerbit Harian KOMPAS, 1999. 
Poerwodarminto, W. J. S. Kamus Umum Bahasa Indonesia. Jakarta: Balai Pustaka, 1996.

Poespoprojo, Wasito. "Hermeneutik Filsafati Relevansi Dari Beberapa Perspektifnya Bagi Kebudayaan Indonesia," Disertasi, Universitas Padjadjaran, 1985.

Rahardjo, Dawam, ed. Pesantren dan Pembaharuan. Jakarta: LP3ES, 1985.

Rawls, John, A. Theory of Justice. USA: Harvard University Press, 1997.

Russel, Betrand. History of Western Philosophy. British: Contemporary Brit ish Philosophy, 1956.

Rahim, Abd. Sepuluh Wasiat Tuhan. Yogyakarta: Bina Usaha, 1983.

Ruslani. Masyarakat Kitab dan Dialog antar Agama (Studi atas Pemikiran Muhammad Arkoun). Yogyakarta: Bintang, 2000.

Raef, Zaini Shofari, ed. Membangun Demokrasi. Bandung: Remaja Rosdakarya, 1999.

Salim, HS Hairus. Menggerakkan Tradisi. Yogyakarta: LKiS, 2001.

Sagiv, David. Islam Otentisitas Liberalisme. Diterjemahkan Yudian W. Asmin, Yogyakarta: LKiS, 1997.

Sahil, Asharuddin. Indeks Al-Qur'an. Bandung: Mizan, 1996.

Sitompul, Einar M. Nahdlatul Ulama dan Pancasila. Jakarta: Pustaka Sinar Harapan, 1989.

Suaedy, Ahmad, ed. Pergulatan Pesantren dan Demokratisasi. Yogyakarta: LKiS, 1999.

—_ ed. Kyai dan Demokrasi. Jakarta: P3M, 2000.

Shihab, Alwi. Islam Inklusif. Bandung: Mizan, 1998.

Syaraf, Muhammad. al-Fikr al-Siyāsî̀ fī al-Isläm. Egypt: Dar al-Ma'arif alJamiah, 1986.

S., Ahmed, Akbar. Citra Muslim: Tinjauan Sejarah dan Sosiologi. Jakarta: Erlangga, 1992.

Syafi'i Ma'arif, Ahmad. Membumikan Islam. Yogyakarta: Pustaka Pelajar, 1996.

Sumarthana, TH. Kritik dan Identitas Agama. Yogyakarta: Pustaka Pelajar, t.th.

Sumaryono, E. Hermeneutik; Sebuah Metode Filsafat. Yogyakarta: Kanisius, 1993.

Syafi'i Anwar, Muhammad. Pemikiran dan Aksi Islam Indonesia: Sebuah Kajian Politik tentang Cendekiawan Muslim Orde Baru. Jakarta: Param adina, 1995.

Syu'di, Abdurrahman Nasyir. Tafsir Kalam Manan. Riyad: Ibn Sa'ud, 1410 H. Syalba, Ahmad. al-Siyāsah fī al-Fikr al-Islāmī. Kairo: Dār al-Ulūm, 1983. 
Saksono, Widji. Mengislamkan Tanah Jawa: Telaah atas Metode Dakwah Walisongo. Bandung: Mizan, 1995.

Simuh. Sufisme Jawa: Transformasi Tasawuf Islam ke Mistik Jawa. Yogyakarta: Yayasan Bintang Budaya, 1995.

Tower Sargent, Lyman. Ideologi Politik Kontemporer. Diterjemahkan oleh Sahat Simamora. Jakarta: Bina Aksara, 1986.

Kitab Kuning: Pesantren dan Tarekat. Bandung: Mizan, 1998.

Veeger, K. J. Realitas Sosial: Refleksi Filsafat Sosial atas Hubungan Individu Masyarakat dalam Cakrawala Sejarah Sosiologi. Jakarta: Gramedia, 1993.

Woodward, Mark R, ed. Jalan Baru Islam: Memetakan Paradigma Mutakhir Islam Indonesia. Diterjemahkan oleh Hassan Ali Fauzi. Bandung: Mizan, 1998.

Wahid, Abdurrahman. "Hubungan Antaragama, Dimensi Internal dan Eksternalnya", Dian/Interfidei (t.th), 3-12.

(1994).

__ . "Pesantren dan Kesusastraan Indonesia." KOMPAS, 16 November 1973.

. "Pengembangan Fiqh yang Kontekstual," Jurnal Pesantren, No. 2, Vol. II (1985)

__ . "Hindari Negara Berasumsi Agama", Media Indonesia, Jum'at 13 November 1998, 6 .

- Islam Anti Kekerasan, dan Transformasi Nasional. Diterjemahkan oleh

M. Taufiq Rahman. Yogyakarta: LKiS, 1998. . Muslim di Tengah Pergumulan. Jakarta: Leppenas, 1981.

Wahjoet om o. Perguruan Tinggi Pesantren. Jakarta: Gema Insani, 1997.

Yuliyatun. "Teori Modeling Psikologi Kepribadian: Studi Peziarah Walisongo dalam Pengembangan Kepribadian." Tesis PPs KTTI Kajian Islam dan Psikologi UI Jakarta, 2007.

Ziemek, Manfred. Pesantren dalam Perubahan Sosial. Diterjemahkan oleh B.B. Sandjojo. Jakarta: P3M, 1986.

Zain, Faishal A. Helmy. Agama dan Kekerasan. Jakarta: PP-IPNU, 1999. 